\title{
COMMENTS
}

\section{DEFINING THE BOUNDARIES OF THE ADVERSE DOMINATION DOCTRINE: IS THERE ANY REPOSE FOR CORPORATE DIRECTORS?}

\author{
MICHAEL E. BAUGHMAN†
}

\section{INTRODUCTION}

Following the massive failure of the savings and loan industry, the federal government sought to recover some of the enormous losses to the banking system and federal insurance coffers from those responsible for the management of these institutions. The authority was placed in the hands of the Resolution Trust Corporation (RTC), Congress's avenging angel. On behalf of failing corporations, the RTC brought hundreds of suits against former officers and directors. ${ }^{1}$ The RTC, however, was inhibited by a serious obstacle-many of these claims were barred under applicable state statutes of limitations. The RTC needed a mechanism to resurrect these otherwise stale claims. It found such a device in the doctrine of adverse domination.

During the early decades of this century, some courts refused to allow a corporation's cause of action against its board of directors to accrue as long as the board remained in control of the corporation, thus precluding the running of the statute of limitations. ${ }^{2}$

† B.A. 1993, Cornell University; J.D. Candidate 1996, University of Pennsylvania. This Comment is dedicated to my family and friends, whose support and encouragement have made this Comment and all I have done possible. Thank you.

${ }^{1}$ See, e.g., Edward L. Morris, SE'L Suits: Unjust, Yes but Coming to an End, NAT'L L.J., Oct. 18, 1993, at 15 (noting that there are " 300 pending suits against the former managers and advisors of some 200 institutions"); Susan Schmidt, Arizona Governor Terms RTC Suit "Witch Hunt," WASH. POST, Jan. 22, 1992, at F1 (describing Arizona Governor J. Fife Symington's complaint that the RTC pursued claims too aggressively).

${ }^{2}$ See, e.g., Adams v. Clarke, 22 F.2d 957, 959 (9th Cir. 1927) ("As trustees in exclusive control of the bank's affairs, [the directors] cannot take advantage of inaction for which they alone are responsible [to prevent the running of the statute of limitations]."); Schilling v. Parman, 35 F.2d 780, 781 (D. Or. 1928) ("[T] he statute of limitations will not run in favor of the directors of a bank who have the control and management of its affairs while they remain in control."); $f$. Curtis v. Connly, 257 U.S. 260, 263-64 (1921) (conferring knowledge of director wrongdoing to a bank when three new directors were placed on board). 
The rationale behind this early adverse domination doctrine was that control of a corporation by those alleged to have harmed it rendered the corporation incapable of bringing suit. ${ }^{3}$ The doctrine was rarely used after $1940,{ }^{4}$ until the RTC discovered that it could use the doctrine to revive claims against former directors of financial institutions under the Financial Institutions Reform, Recovery, and Enforcement Act of 1989 (FIRREA). ${ }^{5}$

The present formulation of the adverse domination doctrine varies in application depending on the jurisdiction. Most courts that accept adverse domination, however, do so for the same underlying purpose: "[T]he corporation which can only act through the controlling wrongdoers cannot reasonably be expected to pursue a claim which it has against them until they are no longer in control." Application of the doctrine tolls the running of the statute of limitations for a corporation's cause of action against its directors until those directors no longer control the corporation.

It is now generally accepted that state law governs the tolling of statutes of limitations under FIRREA. ${ }^{7}$ The increase of litigation

${ }^{3}$ See Schilling, 35 F.2d at 781 (comparing the relationship to that of a cestui que trust); Whitten v. Dabney, 154 P. 312, 315-16 (Cal. 1915) (comparing the disability of a corporation to the "minority of an infant"); see also Note, The Statute of Limitations in Stockholders' Derivative Suits Against Directors, 39 Colum. L. Rev. 842, 857 (1939) (arguing that "although directors are not ordinarily trustees, the fact of control puts the corporation in the position of a cestui of a trust, disabled from making an adverse claim").

${ }^{4}$ See Resolution Trust Corp. v. Scaletty, No. 72,230, 1995 WL 111986, at *4 (Kan. Mar. 17, 1995) (noting that "[m]ost reported cases referring to the [adverse domination] doctrine were decided in the 1980's and '90's'). But see International Rys. of Cent. Am. v. United Fruit Co., 373 F.2d 408, 414 (2d Cir.) (applying the adverse domination doctrine), cert. denied, 387 U.S. 921 (1967); Federal Deposit Ins. Corp. v. Bird, 516 F. Supp. 647, 651 (D.P.R. 1981) (same). Because it was poorly understood, the adverse domination doctrine was used infrequently; with the increasing use of fraudulent concealment and the discovery rule, see infra part $1 . B$, it was all but forgotten.

${ }^{5}$ Pub. L. No. 101-73, 103 Stat. 183 (codified in scattered sections of 12 U.S.C., 15 U.S.C., and 18 U.S.C.); see infra notes 58-70 and accompanying text (discussing FIRREA).

${ }^{6}$ Resolution Trust Corp. v. Farmer, 865 F. Supp. 1143, 1151 (E.D. Pa. 1994).

${ }^{7}$ See O'Melveny \& Myers v. Federal Deposit Ins. Corp., 114 S. Ct. 2048, 2054 (1994) (holding that because the RTC originally brought state-law claims, state law governs the question of imputation of knowledge to the FDIC from the corporate officers and directors); Resolution Trust Corp. v. Artley, 28 F.3d 1099, 1102 (11th Cir. 1994) (applying state law to the question of adverse domination based on the O'Melveny rationale). But see Farmers \& Merchants Nat'l Bank v. Bryan, 902 F.2d 1520,1522 (10th Cir. 1990) (applying federal common law to toll the statute of limitations under the adverse domination doctrine). 
involving adverse domination under FIRREA has begun to mold state law on the issue ${ }^{8}$ and has increased the likelihood that the doctrine will be used more frequently to toll the statutes of limitations in other lawsuits against directors of corporations. ${ }^{9}$ Thus, the issue will be resolved in state courts, using the law as it develops under FIRREA to shape the development of adverse domination in these state courts. ${ }^{10}$ It is especially important that the doctrine be clearly understood so that state courts confronted with allegations of adverse domination will understand its proper application.

This Comment has two basic purposes: to discern the true nature of the adverse domination doctrine and to determine whether the result is a desirable rule for courts to apply. First, some grounding in limitations law and the nature of adverse domination is necessary. Thus, Part I will discuss the historical origins of statutes of limitations, their underlying purposes, and the development of the law regarding the tolling of these statutes. Part II will analyze the specific application of the adverse domination doctrine, concentrating on the increased use of the doctrine in the federal courts by the RTC and the Federal Deposit Insurance Corporation (FDIC) under FIRREA. This Part will expose the four primary inconsistencies in the application of the doctrine: the degree of domination required by the board of directors, the required level of culpability to which directors' actions must rise, whether the doctrine is applicable to toll the statute of limitations against nondirectors, and the burden of proof. Part III will analyze adverse domination under corporate and agency law to determine the legal posture of the doctrine under limitations law. This analysis will reveal that the theoretical underpinnings of the doctrine are most analogous to the discovery rule, another commonlaw method of delaying the accrual of a cause of action.

With this essential structure established, Part IV will apply adverse domination as a variant of the discovery rule, resolving the

${ }^{8}$ For example, the Farmer court noted that Pennsylvania had not explicitly recognized the doctrine of adverse domination but held that the state supreme court likely would find it applicable as a variant of the discovery rule and the fraudulent concealment doctrine. See Farmer, 865 F. Supp. at 1152-54.

${ }^{9}$ See, e.g., Clark v. Milam, 452 S.E.2d 714, 718-20 (W. Va. 1994) (adopting the adverse domination doctrine in the context of an insurance company).

${ }^{10}$ See Resolution Trust Corp. v. Scaletty, No. 72,230, 1995 WL 111986, at *3-*7 (Kan. Mar. 17, 1995) (developing adverse domination doctrine for Kansas); Clark, 452 S.E.2d at 718 (developing adverse domination for West Virginia using RTC and FDIC cases). 
inconsistent application that has plagued its history in the federal courts. Analyzing adverse domination under the discovery rule requires a board of directors in which all knowledgeable directors are wrongdoing directors. The directors need only be negligent for the rule to apply, and the doctrine may also be applied to toll a corporation's cause of action against a nondirector who was involved in the underlying transaction. Finally, the burden of proving domination should be placed on the plaintiffs.

Having satisfied the first goal of discerning a uniform rule that courts are likely to apply according to contemporary case law, this Comment then questions the desirability of such a rule. Part V will analyze the effects of adverse domination, determining that its application would almost entirely eliminate the important policy goal behind statutes of limitations-repose. It will be argued that courts have become extremely liberal in their application of the discovery rule because they believe that the limitations periods prescribed by legislatures are too short. As a response, this Comment will suggest that legislatures supplement their statutes of limitations with longer statutes of repose (limitation periods that cannot be tolled by courts), which would create an upper limit to the time in which a cause of action may be brought.

\section{The History of Statutes of Limitations AND the ORIGINS OF TOLLING PROVISIONS}

Statutes of limitations restrict the amount of time in which plaintiffs may bring their causes of action to court. ${ }^{11}$ Statutes of limitations were originally strict statutes of repose that prevented plaintiffs from bringing suit after the prescribed time periods unless the statutes explicitly provided exceptions. ${ }^{12}$ Eventually, however, statutes of limitations became subject to provisions that tolled the

${ }^{11}$ See, e.g., 42 PA. Cons. STat. ANN. \$§ 5501-5574 (1981 \& Supp. 1994) (Pennsylvania's statutes of limitations); WASH. REV. CODE ANN. $\$ \$ 4.16 .005-.370$ (West 1988 \& Supp. 1994) (Washington's statutes of limitations); see also Christopher R. Leslie, Den of Inequity: The Case for Equitable Doctrines in Rule 10b-5 Cases, 81 CAL. L. REv. 1587,1589 (1993) ("A statute of limitations defines the time period in which a plaintiff must bring suit against a defendant. As a rule, if the statute of limitations expires, a plaintiff may not bring a suit, regardless of its merits."); Developments in the Law-Statutes of Limitations, 63 HARV. L. REV. 1177, 1179 (1950) [hereinafter Developments] (describing the form of typical statutes of limitations).

12 See Gail L. Heriot, A Study in the Choice of Form: Statutes of Limitation and the Doctrine of Laches, 1992 B.Y.U. L. REV. 917, 927 ("In the early nineteenth century, most American courts applied statutes of limitation quite formalistically . ..."). 
statutes under certain circumstances, thereby extending the time in which plaintiffs could bring suit. ${ }^{13}$ This Part will explore the origins of limitations law, both at law and in equity, and the purposes served by statutes of limitations. This Part will then explore the development of tolling provisions from their origins in courts of equity under the doctrine of laches to their current expansive use in courts of law under the discovery rule.

\section{A. The Development of Statutes of Limitations}

The history of limitations of action extends back at least to Roman times, when limitations were placed on actions to recover real property. ${ }^{14}$ Early English common-law courts placed no time limitations on causes of action, believing this to be "the responsibility or prerogative of the king or the Parliament, which acted infrequently and on an ad hoc basis." 15 The modern era of statutes of limitations did not begin until the Limitations Act of 1623 was enacted. ${ }^{16}$ This statute, promulgated under the reign of James I, "provided specific lengths of time for numerous real property and personal actions." ${ }^{\text {17 }}$ Certain explicit disabilities suspended the running of the statute. ${ }^{18}$ Because the English legal system was the basis of American law, American legislatures enacted general statutes of limitations early in their histories. ${ }^{19}$

Statutes of limitations generally are perceived as having two purposes: a "substantive" purpose in granting repose to defendants and a "procedural" purpose in encouraging plaintiffs to bring suit in a timely manner. ${ }^{20}$ The substantive purpose of repose for

${ }^{13}$ See infra notes 33-54 and accompanying text (describing the development of laws permitting the tolling of statutes of limitations).

"4 See RUDOLPH SOHM, THE INSTITUTES: A TEXTBOOK OF THE HisTORY AND SYSTEM OF ROMAN PRIVATE LAW 282-84 (James C. Ledlie trans., Oxford Univ. Press 3d ed. 1907); Heriot, supra note 12, at 923; Developments, supra note 11, at 1177.

${ }^{15}$ Heriot, supra note 12 , at 924 .

${ }^{16}$ Limitations Act, 1623, 21 Jam., ch. 16 (Eng.); see also Heriot, supra note 12, at 926 (stating that the Limitations Act "mark[ed] the advent of reasonably effective and systematic rules to govern time limitation"); Developments, supra note 11, at 1178 ("The Limitations Act of 1623 marks the beginning of the modern law of limitations on personal actions in the common law.").

${ }^{17}$ Heriot, supra note 12 , at 926 .

${ }^{18}$ See id. (explaining that the Limitations Act could be tolled for "infancy, insanity, imprisonment, coverture, and absence from the realm").

${ }^{19}$ See Developments, supra note 11, at 1179.

${ }^{20}$ See Sun Oil Co. v. Wortman, 486 U.S. 717, 736 (1988) (Brennan, J., concurring) ("The statute of limitations a State enacts represents a balance . . . of its procedural interest in freeing its courts from adjudicating stale claims and its substantive interest 


\section{defendants is the primary, driving force behind these statutes:}

Statutes of limitation ... in their conclusive effects are designed to promote justice by preventing surprises through the revival of claims that have been allowed to slumber until evidence has been lost, memories have faded, and witnesses have disappeared. The theory is that even if one has a just claim it is unjust not to put the adversary on notice to defend within the period of limitation and that the right to be free of stale claims in time comes to prevail over the right to prosecute them. ${ }^{21}$

This right of repose for defendants makes intuitive sense. For example, it would be unfair and unjust to hold a director of a corporation liable for simple negligence forty years after the alleged infraction. ${ }^{22}$

Although repose to defendants is the primary purpose of statutes of limitations, encouraging timely action by plaintiffs to promote the efficient management of the court system is an important secondary goal. ${ }^{23}$ By promoting prompt filing of suits, the courts, and presumably society, benefit by avoiding excessive backlogs of ancient causes of action. ${ }^{24} \mathrm{~A}$ careful look at both

in giving individuals repose from ancient breaches of law."); Wood v. Carpenter, 101 U.S. 135, 139 (1879) ("Statutes of limitation are vital to the welfare of society and are favored in the law. . . They promote repose by giving security and stability to human affairs. . . They stimulate to activity and punish negligence."); Developments, supra note 11, at 1185 (stating that statutes of limitations grant repose to defendants and relieve courts of the burden of hearing stale claims); Neil E. Grayson, Note, Defenses to the Statute of Limitations in Federal Securities Cases: The Fraudulent Concealment Doctrine and the Investment Decision Doctrine, 38 S.C. L. REv. 789, 789 (1987) (noting that statutes of limitations encourage prompt filing of suits and protect potential defendants).

${ }^{21}$ Order of R.R. Telegraphers v. Railway Express Agency, 321 U.S. 342, 348-49 (1944); see also Developments, supra note 11, at 1185 ("The primary consideration underlying [statutes of limitations] is undoubtedly one of fairness to the defendant."); Note, supra note 3, at 843 ("The general policy of the statute of limitations is one of repose ...." (footnote omitted)).

${ }^{22}$ This important concept will be illustrated through the use of a hypothetical. See infra text accompanying notes 211-16.

${ }^{23}$ See Developments, supra note 11, at 1185.

${ }^{24}$ See Christopher P. Edwards, Tyson v. L'eggs Products, Inc.: The North Carolina Court of Appeals Provides a Solution to the Business Name Game, 66 N.C. L. REV. 1064, 1077 (1988) ("North Carolina would be well-advised to adopt a . . statute that strives to equalize society's interest in affording injured plaintiffs a meaningful opportunity for legal recourse with the concomitant interest in maintaining an efficient judicial system."); David H. Hollander, Jr. et al., Survey, Developments in Maryland Law, 198889, 49 MD. L. REV. 750, 779-82 (1990) (discussing the importance of judicial economy and expressing concern as to whether the discovery rule will promote such economy); Note, Claim Preclusion in Modern Latent Disease Cases: A Proposal for Allowing Second Suits, 103 HARV. L. REV. 1989, 1994 (1990) (noting that both claim preclusion and 
purposes of statutes of limitations shows that they have one overriding goal: to encourage plaintiffs to bring timely suits, thereby protecting both defendants and the courts. ${ }^{25}$

\section{B. The Development of Doctrines Designed to Toll the Statute of Limitations}

Originally, statutes of limitations were interpreted as rigid legal rules with little room for maneuvering. ${ }^{26}$ Such limitations periods,

statutes of limitations "seek efficiency for the judicial system and tranquility for the defendant"); $c f$. Pennwalt Corp. v. Nasios, 550 A.2d 1155, 1167 (Md. 1988) (noting that the discovery rule promotes judicial economy in medical malpractice cases).

The "substance-procedure dichotomy" is of primary importance for conflict of law purposes when a forum court is entitled to apply its own statute of limitations if the statute is considered procedural. See Wortman, 486 U.S. at 724-26 (noting that at the time of the adoption of the Constitution, statutes of limitations were traditionally procedural for conflict of law purposes, and thus the forum applied its own law); RESTATEMENT (SECOND) OF CONFLICT OF LAWS \$§ 142-143 (1969) (explaining that the forum state's statute of limitations governs, not that of the state in which the action arose, unless the foreign state's statute of limitations bars the substantive right, not merely the remedy). In reality, the practical differences between the substantive and procedural aspects of the statutes are not particularly important in most contexts. For example, in a plurality opinion by Justice Scalia, the Supreme Court in Wortman held that for purposes of conflict of laws, statutes of limitations are procedural, meaning that the forum state is entitled to apply its own statute of limitations to the case. See Wortman, 486 U.S. at 724-25. Justice Scalia noted, however, that statutes of limitations are still substantive for purposes of federal court application of state forum law under the Erie doctrine. See id. at 726-28 (citing Erie R.R. v. Tompkins, 304 U.S. 64 (1938)). The Supreme Court had previously established that federal courts sitting in diversity must apply the forum state's statute of limitations. See Guaranty Trust Co. v. York, 326 U.S. 99, 110 (1945) (noting that because statutes of limitations so "intimately affect recovery or non-recovery a federal court in a diversity case should follow State law" to maintain consistent results among different forums). As the Court noted in Wortman: "Except at the extremes, the term 'substance' and 'procedure' precisely describe very little except a dichotomy, and what they mean in a particular context is largely determined by the purposes for which the dichotomy is drawn." Wortman, 486 U.S. at 726.

${ }^{25}$ The remainder of this Comment will focus on the substantive purpose of limitations-repose. As will be shown, the various applications of the adverse domination doctrine will not undermine the policy of encouraging timely suits. Because adverse domination requires actual ignorance on the plaintiff's part, see infra notes $185-89$ and accompanying text, the policy of encouraging timely suit is not implicated because it is impossible to encourage someone to sue on a cause of action of which she is unaware. Cf. Pennwall, 550 A.2d at 1167 (noting that society's interest in judicial economy is actually enhanced by the discovery rule because otherwise plaintiffs would file actions immediately without full knowledge of the underlying claim). Thus, the procedural policy underlying the statute of limitations will not be affected by the adverse domination doctrine.

${ }^{26}$ See Developments, supra note 11, at 1188-89 ("Apparently the exceptions engrafted upon the limitations statutes by the early courts were a manifestation of a 
however, governed only actions at law. Equity was governed by the doctrine of laches. Laches is based on the same policies as statutes of limitations. ${ }^{27}$ Unlike statutes of limitations, however, laches is left to the discretion of judges. ${ }^{28}$ Thus, laches is a more flexible doctrine-a legal standard, as compared to the rigid legal rules of early statutes of limitations. ${ }^{29}$

The flexibility associated with the doctrine of laches gave impetus to the concept of tolling limitation periods. The general rule of laches focused on plaintiffs' diligence in pursuit of their causes of action. If plaintiffs did not bring suit within a reasonable time period, their actions were barred. ${ }^{30}$ In other words, laches was designed to give plaintiffs a reasonable opportunity to bring suit.

By the end of the nineteenth century, equity courts generally adopted the limitation periods found in analogous statutes of limitations at law. ${ }^{31}$ The doctrine of laches recognized certain disabilities, such as insanity or incapacity, that would prevent the statute of limitations from running. ${ }^{32}$ Equity courts had more discretion than law courts, however, and they began to go beyond the explicit disabilities mentioned in the analogous statute of

reaction to the rigidity of the arbitrarily fixed time periods."); Note, supra note 3 , at 844 ("Definite statutory enactments seeking to make concrete these policies [behind statutes of limitations] have incorporated arbitrary rules, which from time to time have resulted in hard cases." (footnote omitted)).

${ }^{27}$ See Developments, supra note 11 , at 1184 .

${ }^{28}$ See Heriot, supra note 12, at 927 ("In the nineteenth century, equity courts decided the laches question according to the special circumstances of each case. Power was vested in the equity judge to do what was best." (footnote omitted)).

${ }^{29}$ See id. (noting that early American courts applied statutes of limitations rigidly, while equity courts were more liberal with laches); see also infra part V (discussing whether such power should be vested in judges).

${ }^{30}$ See Developments, supra note 11, at 1184 ("Traditionally, there is no laches unless the plaintiffs knew, or reasonably should have known, of the existence of the cause of action, and unless the delay was prejudicial to the defendant."); see also Heriot, supra note 12, at 926-27 (discussing the development of laches).

${ }^{31}$ See H.G. WOOD, A TREATISE ON THE LIMITATION OF ACTIONS AT LAW AND IN EQUITY 108-10 (1883) ("Courts of equity, although not in all cases bound by the statute of limitations . . . have nevertheless . . given effect to the statute . . . "); $c f$. Lyman Johnson, Securities Fraud and the Mirage of Repose, 1992 WIS. L. REV. 607, 641 (noting that "by the mid-19th century, the weight of American authority was that . . . postponement of a limitations period was proper at law as well as in equity").

${ }^{32}$ See, e.g., supra note 18 and accompanying text (stating that early statutes of limitations had several explicit conditions that would toll the statute). Laches granted the same exceptions. See Developments, supra note 11, at 1184 ("Since the concept of laches requires that the plaintiff have had a reasonable opportunity to bring suit, various disabilities similar to those recognized at law will excuse a delay."). 
limitations. Equity courts created the doctrine of equitable tolling in causes of action involving fraud: "[I]n cases where relief is sought upon the ground of fraud on the part of the defendant, the courts, in a proper case, depart from this rule [of strict interpretation], and will give relief, unless the plaintiff has been guilty of unreasonable laches in seeking his remedy in equity." 33 Here lies the origin of the doctrine of fraudulent concealment.

There is some disagreement as to the application of the fraudulent concealment doctrine. In some cases, a bare allegation of fraud in the underlying cause of action is sufficient to toll the statute of limitations under the fraudulent concealment doctrine. ${ }^{34}$ Most of these fraud cases, however, also require that the plaintiff be diligent in determining whether the cause of action exists. ${ }^{35}$ Thus, affirmative misrepresentation by the defendant may not be required when the underlying cause of action is based on fraud. ${ }^{36}$ The modern trend, as fraudulent concealment began to be applied to causes of action other than fraud, is that some type of affirmative concealment is required on the part of the defendant in order for the plaintiff to invoke the doctrine. ${ }^{37}$

${ }^{33}$ Wood, supra note 31 , at 113-14. stated:

${ }^{34}$ See, e.g., Holmberg v. Armbrecht, 327 U.S. 392, 397 (1946). The Holmberg Court

[T] his Court long ago adopted as its own the old chancery rule that where a plaintiff has been injured by fraud and "remains in ignorance of it without any fault or want of diligence or care on his part, the bar of the statute does not begin to run until the fraud is discovered, though there be no special circumstances or efforts on the part of the party committing the fraud to conceal it from the knowledge of the other party."

Id. (quoting Bailey v. Glover, 88 U.S. (21 Wall.) 342, 348 (1874)).

${ }^{35}$ See WOOD, supra note 31 , at 114 (stating that allegations of fraud will not toll the statute if "the plaintiff has been guilty of unreasonable laches in seeking his remedy"); Grayson, supra note 20 , at 803 ("When a fraud goes undiscovered, even though the defendant does nothing affirmative to conceal it, the plaintiff must be duly diligent to toll the limitations period.").

${ }^{36}$ See infra note 116 and accompanying text. Affirmative concealment by the defendant is often not required when the fraud is "inherently difficult to discover." Grayson, supra note 20, at 800 . An example is securities fraud cases. See Leslie, supra note 11, at 1594 ( $[$ [B]ecause securities fraud is often self-concealing, many courts have held that additional fraudulent concealment is not necessary to toll the statute of limitations ..... .").

${ }^{37}$ See John P. Dawson, Fraudulent Concealment and Statutes of Limitation, $31 \mathrm{MICH}$. L. REv. 875, 880 (1933) ("In examining the factual bases for suspension of the statute [courts] were led beyond a scrutiny of the original cause of action and of the plaintiff's later opportunities for discovery, to an emphasis on the means by which the defendant obstructed discovery."); Developments, supra note 11, at 1221 ("Ordinarily the acts of concealment must consist of affirmative misrepresentation or active conduct ...."). 
Just as equity courts were adopting the limitations periods from statutes of limitations for the analogous action at law, law courts began to recognize equitable doctrines for tolling statutes of limitations. ${ }^{38}$ In what one author has termed "convergence," statutes of limitations became more standard-like, and thus lacheslike, as traditional equitable actions became actionable at law. ${ }^{39}$ State law courts adopted the fraudulent concealment doctrine in cases based on nonfraud as well as fraud, often accompanied by legislative actions in the adoption of fraudulent concealment statutes. ${ }^{40}$ Most of these states require some sort of affirmative misrepresentation to toll the statute for fraudulent concealment. ${ }^{41}$

Several recent cases have held that affirmative misrepresentation is generally required, but that it might not be required in cases involving a fiduciary relationship. See, e.g., Litman v. Prudential-Bache Properties, No. CIV.A.12137, 1994 WL 30529, at *3 (Del. Ch. Jan. 14, 1994) ("I think the better rule . . . is that a limitations period may be tolled absent allegations of affirmative acts of concealment by the defendants, where the parties to the litigation stand in a fiduciary relationship to each other ...."); Continental Potash, Inc. v. Freeport-McMoran, Inc., 858 P.2d 66, 77 (N.M. 1993) ("Absent a fiduciary duty to speak on the part of the defendants, however, silence, nondisclosure, or denials of alleged fraudulent conduct are insufficient to constitute fraudulent concealment so as to toll a statute of limitations."), cert. denied, 114 S. Ct. 1064 (1994).

${ }^{38}$ See Moviecolor Ltd. v. Eastman Kodak Co., 288 F.2d 80, 83 (2d Cir.) (recounting how law courts incorporated equitable doctrines for tolling statutes of limitations), cert. denied, 368 U.S. 821 (1961); Heriot, supra note 12, at 954-55 (discussing the courts' tendency to "move the statute of limitations in the direction of . . laches"); Developments, supra note 11, at 1213 (indicating that "equitable grounds for relief became available at law"); Grayson, supra note 20, at 799 (noting that courts applied equitable tolling principles to "congressionally set limitations periods").

${ }^{39}$ See Heriot, supra note 12, at 952-62 (arguing that the doctrine of laches has been absorbed by courts interpreting the statute of limitations); see also Developments, supra note 11, at 1213 (discussing the phenomena in which "equitable grounds for relief became actionable at law"); infra part $\mathrm{V}$ (discussing whether statutes of limitations should be read so broadly).

${ }^{40}$ See, e.g., Alaska Stat. \$ 9.10.055 (1994); ARk. CODE ANN. § 16-56-112 (Michie 1987); Cal. Civ. Proc. Code $\$ 337.15$ (West 1982); 42 PA. Cons. STAT. ANN. $\$ 5532$ (1981).

${ }^{41}$ See, e.g., Hampton v. Taylor, 887 S.W.2d 535, 540 (Ark. 1994) ("Absent active concealment, the statute of limitations is not tolled."); Upah v. Ancona Bros., 521 N.W.2d 895, 905 (Neb. 1994) ("Generally, for fraudulent concealment to delay running of the statute of limitations, the concealment must be manifested by an affirmative act or misrepresentation." ); Krevitz v. City of Philadelphia, 648 A.2d 353, 357 (Pa. Commw. Ct. 1994) (" [M]ere silence or nondisclosure is not enough[;] . . the adversary must commit some affirmative independent act of concealment upon which the plaintiffs justifiably rely. . . ."). But see Wisher v. Higgs, 849 P.2d 152, 160 (Mont. 1993) ("The language of [the fraudulent concealment statute] indicates that simply failure to disclose facts, as opposed to affirmative, fraudulent concealment, is sufficient to toll the statute...."). 
Fraudulent concealment was only the beginning of the tolling revolution in the interpretation of statutes of limitations. More change occurred as courts began to interpret the word "accrue," which appears in most statutes of limitations. ${ }^{42}$ Here lies the origin of the discovery rule, a broader tolling provision than fraudulent concealment that "toll[s] the commencement of the limitations period when [the] plaintiff is excusably unaware of his or her cause of action." 43 The discovery rule focuses on the unfairness to the plaintiff of barring her cause of action for delay when the harm is inherently unknowable. ${ }^{44}$ Fraudulent concealment, in contrast, is similar in nature to estoppel in that it focuses on the conduct of the defendant. ${ }^{45}$

The discovery rule has its modern genesis in medical malpractice cases. The paradigm case is that of a doctor leaving a sponge in a patient. ${ }^{46}$ The discovery rule generally tolls the running of the statute until the plaintiff knows, or reasonably should know, that she

42 One commentator has noted: "As ... equitable grounds for relief became available at law through gradual assimilation or statutory merger, and thus became subject to fixed periods of limitations, the courts adapted their practice to the flexible equity rule by redefining the cause of action to include discovery as a prerequisite to 'accrual.' Developments, supra note 11, at 1213.

${ }^{13}$ Heriot, supra note 12, at 954.

${ }^{14}$ See O'Brien v. Eli Lilly \& Co., 668 F.2d 704, 705-06 (3d Cir. 1981) ("Pennsylvania courts have recognized the potential harshness inherent in a rigid application of the statute and long ago carved out an exception: ignorance of an injury may delay the running of the statute of limitations."); Resolution Trust Corp. v. Farmer, 865 F. Supp. 1143, 1155 (E.D. Pa. 1994) ("It is the 'inherently unknowable' character of the injury that is the critical factor that governs the applicability of the discovery rule." (citing O'Brien, 668 F.2d at 705-06)); Kohler v. Woollen, Brown \& Hawkins, 304 N.E.2d 677, 680 (Ill. Ct. App. 1973) ("It is manifestly unrealistic and unfair to bar a negligently injured party's cause of action before he has had an opportunity to discover that it exists." (citation omitted)); Developments, supra note 11, at 1203 (suggesting that an exception to a statute of limitations is desirable when there is harm the plaintiff is unlikely to discover); William M. Schrier, Note, The Guardian or the Ward: For Whom Does the Statute Toll?, 71 B.U. L. REv. 575, 587 (1991) ("[A] central consideration in applying tolling provisions is the notion that those who receive their salutary effects are blameless for their untimeliness.").

${ }^{45}$ See Farmer, 865 F. Supp. at 1153 ("The doctrine of fraudulent concealment is based on estoppel principles . ..."); Palmer v. Borg-Warner Corp., 838 P.2d 1243, 1249 n.9 (Alaska 1992) (noting that "fraudulent concealment precludes a defendant from relying on the statue [sic] of limitations" (emphasis added)).

${ }^{16}$ See, e.g., Ayers v. Morgan, 154 A.2d 788, 794 ( $\mathrm{Pa}$. 1959) (holding discovery rule applicable where doctor left sponge in patient); see also Heriot, supra note 12, at 955 (noting that the "prototypical example" offered by medical malpractice cases led to the fashioning of discovery rules); Gerald A. McHugh, Jr., The Statute of Limitations and the Discovery Rule: Variations on a Theme of Fairness, 64 PA. B. Ass'N Q. 197, 197 (1993) (noting that Ayers represented a "textbook case" of the discovery rule). 
has been injured by another party. ${ }^{47}$ Thus, the conduct of the defendant as it relates to the plaintiff's discovery is absent from the equation. As long as the defendant is culpable in the underlying cause of action, the accrual of the cause of action against her is postponed until discovery.

The discovery rule has been expanded greatly, mostly by judicial, as opposed to legislative, action. ${ }^{48}$ In many states the discovery rule now applies to causes of action beyond medical malpractice, such as other professional malpractice, ${ }^{49}$ products liability, ${ }^{50}$ and even wrongful death actions. ${ }^{51}$ Indeed, it appears that in some states, almost any tort that causes an "inherently unknowable" injury will be subject to tolling under the discovery rule. ${ }^{52}$

Courts maintain a distinction between fraudulent concealment and the discovery rule because these doctrines serve different purposes. ${ }^{53}$ Fraudulent concealment is designed to estop defen-

${ }^{47}$ See United States v. Kubrick, 444 U.S. 111, 126 (1979) (Stevens, J., dissenting) (noting that a cause of action accrues "when a diligent plaintiff has knowledge of facts sufficient to put him on notice of an invasion of his legal rights"); Farmer, $865 \mathrm{~F}$. Supp. at 1155 ("Under the discovery rule, the statute of limitations begins to run when 'the plaintiff knows, or reasonably should know: (1) that he has been injured, and (2) that his injury has been caused by another party's conduct." (quoting Cathcart v. Keene Indus. Insulation, 471 A.2d 493, 500 (Pa. Super. Ct. 1984))); Melanie T. Hewell, Comment, Extending the Application of the Discovery Rule to Wrongful Death Actions: Where Will Texas Draw the Line?, 38 BAYLOR L. REv. 151, 152 (1986) ("The discovery rule will toll the commencement of the limitations period until the plaintiff knows of or 'discovers' the facts and cause of injury for which he seeks relief.").

${ }^{48}$ See Heriot, supra note 12, at 955-63 (arguing that the expansive discovery rules used in the courts remove the rule-like character given to them by the legislature); Charles F. Scott, For Whom the Time Tolls-Time of Discovery and the Statute of Limitations, 64 ILL. B.J. 326, 327 (1976) ( ${ }^{\text {[ }}$ E]xceptions to various statutes of limitations have been increasingly judicial rather than legislative."); see also infra notes 21619 and accompanying text.

${ }^{49}$ See, e.g., Tom Olesker's Exciting World of Fashion, Inc. v. Dun \& Bradstreet, Inc. 334 N.E.2d 160, 164 (Ill. 1975) (applying discovery rule in cause of action against a credit reporting agency).

${ }^{50}$ See, e.g., Louisville Trust Co. v. Johns-Manville Prod. Corp., 580 S.W.2d 497, 500-01 (Ky. 1979) (holding discovery rule applicable to asbestos litigation); Larson v. Johns-Manville Sales Corp., 399 N.W.2d 1, 4 (Mich. 1986) (same).

${ }^{51}$ See, e.g., Frederick v. Calbio Pharmaceuticals, 152 Cal. Rptr. 292, 294 (Ct. App. 1979); White v. Johns-Manville Corp., 693 P.2d 687, 693 (Wash. 1985) (en banc); $c f$. Benner v. J.H. Lynch \& Sons, Inc., 641 A.2d 332, 336-37 (R.I. 1994) (holding in a wrongful death action that the discovery rule applies at the time of the accident, not from discovery of the cause of the accident).

${ }^{52}$ See, e.g., Hecht v. Resolution Trust Corp., 635 A.2d 394, 399 (Md. 1994) ("Recognizing the unfairness inherent in charging a plaintiff with slumbering on rights not reasonably possible to ascertain, this Court adopted what is known as the discovery rule, which now applies generally in all civil actions." (emphasis added)).

${ }^{53}$ For example, Pennsylvania applies the fraudulent concealment rule in some 
dants from asserting that the cause of action is barred when the defendant is responsible for the plaintiff's failure to bring suit. The discovery rule protects plaintiffs from the harsh effects of a statutory bar when the harm is inherently unknowable. These distinctions must be kept in mind when ascertaining the nature of the adverse domination doctrine. ${ }^{54}$

\section{APPLiCATION OF THE ADVERSE DOMINATION DOCTRINE}

The early common law makes reference to the notion that domination of a board of directors might toll the statute of limitations. ${ }^{55}$ A specific doctrine and rationale, however, did not emerge from this period. ${ }^{56}$ This is not entirely surprising, because litigation surrounding such claims was relatively infrequent. With the massive increase in litigation alleging adverse domination under FIRREA, the actual parameters of the rule are finally being fleshed out.

Until FIRREA was passed in 1989, use of the doctrine was uncommon, with few significant cases being decided in the federal courts and even fewer in the state courts. ${ }^{57}$ When adverse domina-

cases, see Schaffer v. Larzelere, 189 A.2d 267, 269 (Pa. 1963) (noting that fraudulent concealment applies when "defendant causes the plaintiff to relax his vigilance"), and the discovery rule in other actions. See Ayers v. Morgan, 154 A.2d 788, 794 (Pa. 1959) (applying the discovery rule in a medical malpractice case).

${ }^{54}$ See infra part III (determining that adverse domination is a variant of the discovery rule).

Some courts and commentators distinguish between fraudulent concealment and the discovery rule by the way each suspends the statute. The fraudulent concealment doctrine tolls the statute, in that it stops the limitations period from running once it has begun. The discovery rule postpones accrual, in that it prevents the statute from running in the first place. See Developments, supra note 11, at 1220-24 (discussing the distinction between postponement and suspension). These distinctions are important in practice because they affect the amount of time left to bring suit after the disability is removed. From a theoretical standpoint, however, the distinction is of limited importance. See Resolution Trust Corp. v. Scaletty, No. 72,230, 1995 WL 111986, at *5 (Kan. Mar. 17, 1995) ("Whether an accrual or a tolling doctrine is involved, however, may be a distinction without a difference, since the result is the same."); Hecht, $635 \mathrm{~A} .2 \mathrm{~d}$ at $399 \mathrm{n} .11$ (noting that for purposes of the adverse domination doctrine, the distinction makes no practical difference). Thus, it is not explored further in this Comment.

${ }^{55}$ See supra notes 2-3 and accompanying text.

${ }^{56}$ See Note, supra note 3 , at $856-57$ (noting that domination was sometimes just an element of fraudulent concealment, but that at other times it served as a per se rule that tolled the statute).

${ }^{57}$ See Scaletty, No. 72,230, 1995 WL 111986, at *4 (noting that most adverse domination cases were decided in the 1980s and 1990s in the context of failed banks). One of the most significant cases decided before FIRREA was passed is Federal 
tion began to be litigated on a regular basis, the issues behind the doctrine were finally illuminated, but they remained unresolved. After a brief discussion of the structure of FIRREA and the applicable law, this Part examines the four major issues of contention: degree of domination, level of culpability, application of the doctrine to nondirectors, and burden of proof.

\section{A. FIRREA and the Applicable Law}

Following the massive failure of the savings and loan industry, Congress enacted the Financial Institutions Reform, Recovery, and Enforcement Act of $1989^{58}$ (FIRREA) to "restore public confidence in financial institutions. ${ }^{759}$ Along with numerous provisions to increase the stability of the industry, a central purpose of the act was to increase the enforcement powers of federal regulatory agencies. ${ }^{60}$ FIRREA gave the FDIC and the newly created RTC the power to enforce a failed bank's causes of action against its former officers and directors for their negligence or breaches of duty. ${ }^{61}$ This power placed the RTC in the capacity of a receiver. ${ }^{62}$

Deposit Insurance Corp. v. Bird, 516 F. Supp. 647 (D.P.R. 1981). This case is often cited for its clear explanation of why the adverse domination doctrine makes sense. Although the court noted that there was no consensus on the rationale behind the doctrine, see $i d$. at 650-51, the court held that all "these decisions reflect an implicit appreciation of the realities of the shareholders' position .... Is it logical to assume that the directors, in whom the bank has entrusted the discretion to sue, would authorize the initiation of an action against themselves for their own improprieties?" $I d$. at 651 ; see also supra note 4 (discussing possible reasons the doctrine was not used earlier by courts).

${ }^{58}$ Pub. L. No. 101-73, 103 Stat. 183 (codified in scattered sections of 12 U.S.C, 15 U.S.C., and 18 U.S.C.).

59 Norma Hildenbrand, DE゚O Liability: Expansion via Regulation, 111 BANKING L.J. 365,366 (1994).

${ }^{60}$ See id. at 369 ("A core objective of Congress by enacting FIRREA was to expand the enforcement powers of the regulatory agencies."); Charles L. O'Brien \& Lisa M. Cavage, FIRREA: Retroactive Application, Due Process Issues, Right-Duty Analysis and the Statute of Limitations, 108 BANKING L.J. 308, 308-09 (1991) (noting that the Act was "expressly designed' to strengthen the enforcement powers of [f]ederal regulators").

${ }^{61}$ See 12 U.S.C. $\$ \S 1441$ (b)(3)(A), 1821(d) (Supp. V 1993); see also Jett Hanna, Statute of Limitations Issues in FDIC and RTC Claims Against Attorneys Representing Failed Financial Institutions, 12 REV. LITIC. 619, 620 \& n.4 (1993) (noting that FIRREA gave the FDIC and RTC the power to "try to recover [savings and loan] losses through litigation against attorneys for failed financial institutions").

${ }^{62} \mathrm{~A}$ "receiver" is "[a] person appointed by a court for the purpose of preserving property of a debtor pending an action against him, or applying the property in satisfaction of a creditor's claim, whenever there is danger that, in the absence of such an appointment, the property will be lost, removed or injured." BLACK'S LAW DICTIONARY 1268 (6th ed. 1990). 
In the original act, FIRREA contained a provision for determining the statute of limitations governing suits by the FDIC or RTC. ${ }^{63}$ Often the length of the limitations period was a matter of state law, because the statute was interpreted as not reviving stale state-law claims. ${ }^{64}$ There was originally a great deal of confusion whether, under FIRREA, state or federal law should govern the question of tolling the statute of limitations due to adverse domination. The Tenth Circuit generally held that the tolling of the statute was a question of federal common law. ${ }^{65}$ Beginning with the Fifth Circuit Court of Appeals, however, this notion has been widely rejected, and it is now generally held that state law governs the question whether adverse domination should apply to the tolling of the statute of limitations. ${ }^{66}$ The application of state law, rather

${ }^{63}$ The original statute read:

(A) In general

Notwithstanding any provision of any contract, the applicable statute of limitations with regard to any action brought by the [FDIC or RTC] as conservator or receiver shall be-

(i) in the case of any contract claim, the longer of-

(I) the 6-year period beginning on the date the claim accrues; or

(II) the period applicable under State law; and

(ii) in the case of any tort claim, the longer of-

(I) the 3-year period beginning on the date the claim accrues; or

(II) the period applicable under State law.

(B) Determination of the date on which a claim accrues

For purposes of subparagraph (A), the date on which the statute of limitations begins to run on any claim described in such subparagraph shall be the later of-

(i) the date of the appointment of the [FDIC or RTC] as conservator or receiver; or

(ii) the date on which the cause of action accrues.

Financial Institutions Reform, Recovery, and Enforcement Act of 1989, Pub. L. No. 101-73, § 212(a), 103 Stat. 183, 232-33, reprinted in Federal Deposit Ins. Corp. v. Dawson, 4 F.3d 1303, 1306 n.2 (5th Cir. 1993), cert. denied, 114 S. Ct. 2673 (1994).

${ }^{64}$ See Resolution Trust Corp. v. Artley, 28 F.3d 1099, 1101 (11th Cir. 1994) (noting that " $[t]$ he statute "has been interpreted not to revive stale state-law claims acquired by the FDIC'" (quoting Dawson, 4 F.3d at 1307)).

${ }^{65}$ See Farmers \& Merchants Nat'l Bank v. Bryan, 902 F.2d 1520, 1523 (10th Cir. 1990) ("[W]e . . . adopt the theory as part of the federal common law of this circuit."); Resolution Trust Corp. v. Scaletty, No. 92-1101-PFK, 1993 WL 444303, at *3 (D. Kan. Oct. 29, 1993) (applying the rule espoused in Bryan); Resolution Trust Corp. v. Thomas, 837 F. Supp. 354, 359 (D. Kan. 1993) (same).

${ }^{66}$ See Dawson, 4 F.3d at 1309 ("If the FDIC is to toll the state statute of limitations prior to its appointment as receiver under the adverse domination doctrine, it must show the district court that the state law of adverse domination would permit tolling."); see also Artley, 28 F.3d at 1101 ("Defendants argue that Georgia law applies, and that Georgia law does not recognize 'adverse domination' in these circumstances. We agree with defendants."); Federal Deposit Ins. Corp. v. Cocke, 7 F.3d 396, 400 
than federal law, to the question of adverse domination greatly increased the difficulty the RTC and FDIC faced in pursuing these claims. Many courts were reluctant to read a rule of adverse domination into state law unless the doctrine was explicitly recognized. ${ }^{67}$ The decisions barring suit disturbed many members of Congress, because they decreased the effectiveness of the RTC and FDIC's pursuit of claims. ${ }^{68}$ Therefore, Congress amended the statute of limitations in 1994 to prevent the running of the statute under state law for claims based on intentional misconduct. ${ }^{69}$

(4th Cir. 1993) ("Although federal law allows the FDIC . . . to bring . . . claims, the claims are uniquely state-law causes of action .... Therefore, this case does not present the situation in which federal statute authorizes and outlines federal activity, but neglects to furnish a crucial provision that would effectuate the federal activity more appropriately."), cert. denied, 115 S. Ct. 53 (1994). Whether the interpretation of these courts is in fact correct is beyond the scope of this Comment.

${ }^{67}$ See, e.g., Artley, $28 \mathrm{~F} .3 \mathrm{~d}$ at 1101-02 (refusing to adopt the adverse domination doctrine because Georgia law does not recognize it); Cocke, 7 F.3d at 402 (applying the fraudulent concealment doctrine, which requires an affirmative misrepresentation by the defendant, because Virginia does not expressly recognize the adverse domination doctrine).

${ }^{68}$ Senator Metzenbaum was among the most agitated. When Congress set about to amend FIRREA's statute of limitations, he threatened a filibuster because he believed that it did not go far enough since it did not extend the statute of limitations for causes of action based in negligence. Metzenbaum later withdrew his opposition when the Office of Thrift Supervision (OTS) agreed to increase its enforcement of these suits because such suits are not governed by FIRREA's statute of limitations. See Keith Bradsher, Bill Would Curb Suits on S. $\mathcal{E}^{\circ}$ L.' 's, N.Y. TIMES, Sept. 12, 1994, at D1 (noting that Metzenbaum planned to filibuster the interstate banking bill because its savings and loan provision would "effectively prevent Federal regulators from pursuing most negligence cases against the officers, directors, lawyers and accountants of failed savings and loan institutions"); Albert R. Karr, Bank Measure Clears Senate, Goes to Clinton, WALL. ST. J., Sept. 14, 1994, at A20 (noting that Metzenbaum "dropped his opposition after getting assurances . . . that the OTS would use its own considerable powers to pursue" such cases); see also 138 CONG. REC. S15,493 (daily ed. Sept. 28, 1992) (remarks of Sen. Wirth regarding the extension of the statute of limitations).

${ }^{69}$ See Riegel-Neal Interstate Banking and Branching Efficiency Act of 1994, Pub. L. No. 103-328, sec. 201(a), § 1821(d)(14), 108 Stat. 2338, 2368 (to be codified at 12 U.S.C. $\S 1821(\mathrm{~d})(14)(\mathrm{C})$ ). This act provides, in relevant part:

(C) Revival of expired state causes of action.-

(i) In general.-In the case of any tort claim described in clause (ii) for which the statute of limitation applicable under State law with respect to such claim has expired not more than 5 years before the appointment of the Corporation as conservator or receiver, the Corporation may bring an action as conservator or receiver on such claim without regard to the expiration of the statute of limitation applicable under State law.

(ii) Claims described.-A tort claim referred to in clause (i) is a claim arising from fraud, intentional misconduct resulting in unjust enrichment, or intentional misconduct resulting in substantial loss to the institution. 
Adverse domination is no longer needed in intentional tort cases because it is now covered by statute. The amendment resolved the issue in the context of intentional torts only; the statute of limitations question is left open in the context of negligence claims. Thus, the question whether state law recognizes the doctrine of adverse domination remains an important one for many RTC and FDIC cases under FIRREA. ${ }^{70}$

\section{B. Issues of Contention}

\section{The Required Level of Domination}

Perhaps the most widely discussed variation in the application of adverse domination-and the most mired in confusion-is the degree of domination of the board required in order for the corporation to claim the protection of the doctrine. The source of the modern adverse domination claim is International Railways of Central America v. United Fruit Co., ${ }^{71}$ in which the Court of Appeals for the Second Circuit, through the voice of Judge Friendly, first articulated the boundaries of the rule. The court, faced with an allegation of domination such that the statute should be tolled, first noted that prior case law on the question was not particularly clear in establishing the boundaries of the doctrine. ${ }^{72}$ Judge Friendly then provided what appears to be the first definitive statement on the level of domination required of the board in order for the corporation to invoke the doctrine:

One principle emerging with some clarity [from prior cases] is that a plaintiff who seeks to toll the statute on the basis of domination of a corporation has the burden of showing "a full, complete and exclusive control in the directors or officers charged." ... This principle must mean at least that once the facts giving rise to possible liability are known, the plaintiff must effectively negate the possibility that an informed ... director could have induced the corporation to sue. ${ }^{73}$

Id.

${ }^{70}$ Because this Comment determines that negligence is sufficient to invoke the adverse domination doctrine, see infra notes 191-98 and accompanying text, adverse domination is still crucial in RTC claims.

" 373 F.2d 408 (2d Cir.), cert. denied, 387 U.S. 921 (1967).

${ }^{72}$ See id. at 413-14.

${ }^{79} \mathrm{Id}$. at 414 (citations omitted). 
This statement on the required level of culpability became known as the "complete domination test" ${ }^{\prime \prime 4}$ and established the principle of adverse domination in the federal common law. ${ }^{75}$

In some ways the complete domination test created more questions than it answered. Does complete domination require that every director on the board be culpable as to the underlying transaction-a numerical complete domination? Or does complete domination mean that the culpable directors are in such a position that they can completely dominate the board by their influence and control-an influential complete domination? The courts are uncertain, and Judge Friendly himself seemed to recognize the problem. ${ }^{76}$ In Farmers $\mathcal{E}$ Merchants National Bank $v$. Bryan, ${ }^{77}$ for example, the court embraced an influential complete domination approach. The Bryan court was asked to find that adverse domination did not apply as a matter of law because there were two outside directors on the board of directors who were not accused of wrongdoing. ${ }^{78}$ The court refused, noting that the question of domination is one of fact, and that "a plaintiff may also demonstrate adverse domination by proving that an informed director, though capable of suing, would not do so."79 Still, under the Bryan approach, the plaintiff must prove there was no one capable or willing to sue. ${ }^{80}$ Other courts, however, tend to favor a numerical complete domination test. ${ }^{81}$

${ }^{74}$ See Federal Deposit Ins. Corp. v. Dawson, 4 F.3d 1303, 1309 (5th Cir. 1993) (noting that "complete domination" is one of two competing theories), cert. denied, 114 S. Ct. 2673 (1994); Heidi H. Mayor et al., Ninth Survey of White Collar Crime: Financial Institutions Fraud, 31 AM. CRIM. L. REV, 647, 670-71 (1994) (same).

${ }^{75}$ See Farmers \& Merchants Nat'l Bank v. Bryan, 902 F.2d 1520, 1522 (10th Cir. $1990)$ ("[O]ther courts have adopted the theory of 'adverse domination' as another equitable vehicle under federal common law for tolling the statute of limitations." (citing International Rys., 373 F.2d at 414)).

${ }^{76}$ See International Rys., 373 F.2d at 414; see also infra note 111 (discussing International Railways in greater depth).

77902 F.2d 1520 (10th Cir. 1990).

${ }^{78}$ See id. at 1523.

${ }^{79} I d$.

${ }^{80}$ See id.

${ }^{81}$ Resolution Trust Corp. v. Farmer, 865 F. Supp. 1143 (E.D. Pa. 1994), relied on the domination of the directors as a group, as opposed to domination by one or two directors. See id. at 1158 . It appears that no court has required the plaintiff to prove that every director was culpable. Courts have, however, begun to recognize that the test is a numerical one. See, e.g., Resolution Trust Corp. v. Bright, 872 F. Supp. 1551, 1563 (N.D. Tex. 1995) (noting that a numerical approach to adverse domination is proper in the context of a majority test). 
Although the complete domination test is still applied in some jurisdictions, ${ }^{82}$ the trend seems to be toward a "majority test," in which a plaintiff "must show only that a majority of the board members were wrongdoers during [the] period the plaintiff seeks to toll the statute. ${ }^{n 3}$ The Fifth Circuit, where a great deal of litigation involving adverse domination has occurred, adopted the majority test under Texas law in Federal Deposit Insurance Corp. v. Dawson. ${ }^{84}$ The court reasoned that "the mere existence of a culpable majority on the board is so likely to preclude the corporation from filing suit against the wrongdoers that tolling is thereby justified." ${ }^{\text {"5 }}$ The majority test is exclusively a numerical one. ${ }^{86}$ Although there is no consensus among jurisdictions as to whether the majority test or complete domination test should be applied, the majority test seems to have the upper hand. ${ }^{87}$

${ }^{82}$ See, e.g., Farmer, 865 F. Supp. at 1157 ( $[$ TT]he plaintiff must negate the possibility that an informed person or persons could have induced the corporation to initiate suit.").

${ }^{83}$ Federal Deposit Ins. Corp. v. Dawson, 4 F.3d 1303, 1310 (5th Cir. 1993), cert. denied, 114 S. Ct. 2673 (1994); see also D. Annette Fields et al., The Statute of Limitations, in DEFENDING BANK AND THRIFT DIRECTORS AND PROFESSIONALS 143, 163 (1994) (noting that most courts use the majority test).

844 F.3d 1303 (5th Cir. 1993), cert. denied, 114 S. Ct. 2673 (1994).

${ }^{85} \mathrm{Id}$. at 1310 .

${ }^{86}$ See Resolution Trust Corp. v. Bright, 872 F. Supp. 1551, 1563 (N.D. Tex. 1995) (noting that Dawson can be understood as "support[ing] a numerical interpretation of the majority test").

${ }^{87}$ See, e.g., Federal Sav. \& Loan Ins. Corp. v. Williams, 599 F. Supp. 1184, 1193-94 (D. Md. 1984) (noting that the "better reasoned" cases apply the majority test); Hecht v. Resolution Trust Corp., 635 A.2d 394, 402 (Md. 1994) ("Several versions of the doctrine exist, but the one which appears to be the most common, and which has the greatest effect on accrual or tolling, is the 'disinterested majority' version ....."); Hanna, supra note 61 , at 654 ("The most common rule has been that the tolling continues as long as a majority of the board of directors controls the institution."). For further discussion of the distinction between the two versions, see 3A STEPHEN M. FLANAGAN \& CHARLES R.P. KEATING, FletcheR CYClOPEDIA OF THE LAW OF PRIVATE CORPORATIONS $\$ 1306.2$ (1986) (noting the inconsistencies); Mayor et al., supra note 74, at 670-71 (discussing the two different approaches to adverse domination). It is worth pointing out that at least one court has held that "control sufficient to warrant the tolling of the statute of limitations may occur where culpable directors constitute less than a majority of a board of directors." Resolution Trust Corp. v. Thomas, 837 F. Supp. 354, 359 (D. Kan. 1993). This is yet more evidence of the inconsistent application of the rules, especially because the Thomas court is in the Tenth Circuit and should be subject to the holding in Bryan. See supra notes 7780 and accompanying text (discussing Bryan). 


\section{The Degree of Culpability}

The degree of culpability that a plaintiff must allege against directors also varies among jurisdictions. In many cases a distinction between gross and ordinary negligence might not be important, because, under the business judgment rule, directors must be guilty of gross negligence to be held liable for breach of duty. ${ }^{88}$ In the context of financial institutions, however, the distinction is of special importance because directors of these institutions traditionally have been held to a higher standard of care. ${ }^{89}$ In addition, courts will ease the requirement of gross negligence in a variety of other contexts. ${ }^{90}$ Thus, when a corporation is able to sue its directors for negligence, it is important to know whether adverse domination will apply to toll the statute of limitations.

In the context of FIRREA litigation, some federal jurisdictions, in applying the appropriate state law, require that the plaintiff allege some type of affirmative misconduct by the directors to gain the protection of the adverse domination rule. ${ }^{91}$ Whether gross

${ }^{88}$ See Smith v. Van Gorkom, 488 A.2d 858, 873 (Del. 1985) ('[T]he concept of gross negligence is also the proper standard for determining whether a business judgment reached by a board of directors was an informed one."); Aronson v. Lewis, 473 A.2d 805, 812 (Del. 1984) ("[U]nder the business judgment rule director liability is predicated upon concepts of gross negligence. "); Shlensky v. Wrigley, 237 N.E.2d 776, 779-80 (Ill. Ct. App. 1968) (explaining that a court of equity cannot interfere with the board of directors' control over a corporation unless the directors have acted fraudulently or breached a duty of good faith).

${ }^{89}$ See Litwin v. Allen, 25 N.Y.S.2d 667, 678 (1940) ("Undoubtedly, a director of a bank is held to stricter accountability than the director of an ordinary business corporation."); ROBERT W. HAMILTON, CASES AND MATERIALS ON CORPORATIONS 75558 (5th ed. 1994) (discussing the higher standard of care for bank directors); Hildenbrand, supra note 59, at 379 ("The common law has always exacted a higher standard on directors and officers of financial institutions."); see also Billman v. State of Maryland Deposit Ins. Fund Corp., 593 A.2d 684, 698 (Md. Ct. Spec. App.) (noting that the standard of care of banking officers is based on standards of the banking industry), cert. denied, 599 A.2d 447 (Md. 1991). But see Selheimer v. Manganese Corp. of Am., 224 A.2d 634, 642-43 (Pa. 1966) (holding that a recently enacted statute removed any higher standard of care that might be owed by officers or directors of a banking institution).

${ }^{90}$ See, e.g., Louisiana World Exposition v. Federal Ins. Co., 864 F.2d 1147, 1151 (5th Cir. 1989) (noting that nonprofit directors were typically held to a higher standard of care); $c f .1$ WILLIAM E. KNEPPER \& DAN A. BAILEY, LIABILITY OF CORPORATE OFFICERS AND DIRECTORS \& 3-4, at 101 (5th ed. 1993) (noting that the "degree of care required depends upon the circumstances under which the director acted").

${ }^{91}$ See Federal Deposit Ins. Corp. v. Dawson, 4 F.3d 1303, 1312 (5th Cir. 1993) ("[T]he adverse domination theory is inappropriate when the majority of the board is merely negligent."), cert. denied, 114 S. Ct. 2673 (1994); Resolution Trust Corp. v. Farmer, 865 F. Supp. 1143, 1157 (E.D. Pa. 1994) ("[P]laintiff must show that [the dominators] 
negligence is necessary to satisfy this heightened culpability test is not clear. ${ }^{92}$ Other courts allow adverse domination to be used against directors even for simple negligence. ${ }^{93}$

\section{Application of the Adverse Domination Doctrine to Toll the Statute on a Corporation's Cause of Action Against Third Parties}

Jurisdictions also disagree on whether a corporation may argue that the adverse domination of its board of directors should toll the statute of limitations for the corporation's causes of action against nondirectors. For example, a corporation may seek to toll the statute of limitations on a malpractice claim against its attorneys. ${ }^{94}$ Usually, such cases involve a third party who in some way benefited from the culpable activity of the dominating directors. ${ }^{95}$ A few courts have extended the application of the doctrine to third parties. $^{96}$ Other courts, most notably the Fifth Circuit in its

were active participants in true wrongdoing, that is, their conduct was more culpable than mere negligence.").

${ }^{92}$ Compare Federal Deposit Ins. Corp. v. Henderson, 849 F. Supp. 495, 498 (E.D. Tex. 1994) (finding that gross negligence is sufficient to invoke the application of adverse domination) with Resolution Trust Corp. v. Acton, 844 F. Supp. 307, 317 (N.D. Tex. 1994) (finding that gross negligence is not sufficient to invoke the application of adverse domination), affd, No. 94-10375, 1995 WL 144124 (5th Cir. April 4, 1995). The affirmance of Acton by the Fifth Circuit Court of Appeals shortly before the publication of this Comment would seem to resolve this issue within the Fifth Circuit. See also Resolution Trust Corp. v. Bright, 872 F. Supp. 1551, 1563 (N.D. Tex. 1995) (holding that actionable fraud, rather than constructive fraud, is required to invoke the doctrine).

${ }^{93}$ See, e.g., Resolution Trust Corp. v. O'Bear, Overholser, Smith \& Huffer, 840 F. Supp. 1270, 1284 (N.D. Ind. 1993) (comparing adverse domination to the discovery rule and holding that "a corporate 'plaintiff' has not discovered alleged negligence until that negligence is discovered by those who can be expected to act to redress the entity's interest" (emphasis added)); see also infra part IV.B (noting that the required level of culpability should be negligence and citing cases which have so held).

I See, e.g., O'Bear, $840 \mathrm{~F}$. Supp. at 1284-85 (applying the adverse domination doctrine in a case in which the RTC brought an action against counsel of a failed institution); Resolution Trust Corp. v. Gardner, 798 F. Supp. 790, 794-96 (D.D.C. 1992) (granting RTC's motion to toll the statute of limitations in a suit to recover improper payments made by a failed savings and loan to its attorney).

${ }_{95}$ In Gardner, the attorney was accused of receiving improper payments from the corporation. See Gardner, 798 F. Supp. at 791-92; see also Mayor et al., supra note 74, at 672 ("Directors and officers, who themselves are guilty of wrongdoing, would certainly not bring an action against a third party who benefited from the same fraudulent activity, out of fear that their own culpable conduct might be discovered.").

${ }_{96}$ See, e.g., Bornstein v. Poulos, 793 F.2d 444, 448 (1st Cir. 1986) (concluding that the lower court's reasoning with regard to tolling the statute of limitations extended 
application of Texas law, have balked at this expansive reading of the doctrine. ${ }^{97}$ The resolution of the third-party issue may have the most far-reaching effects because it could expand the use of adverse domination to everyone who has any contact with a corporation.

\section{The Burden of Proof}

As the use of adverse domination increases, more intricate problems concerning the practical functioning of the doctrine are being discussed. Generally, courts place the burden of proving adverse domination on the plaintiff. ${ }^{98}$ In Hecht $v$. Resolution Trust Corp. ${ }^{99}$ however, the Maryland Court of Appeals adopted what it termed "the disinterested majority" test. ${ }^{100}$ Under this rationale, the burden of production falls on the plaintiff to show that a majority of the board is culpable. ${ }^{101}$ Once this has been shown, the burden shifts to the defendant, who presumably has better access to information, ${ }^{102}$ to prove that someone on the board was willing and able to bring suit. ${ }^{103}$ Contrary to the views of

to the attorney, who also had a fiduciary duty to the corporation); Mosesian v. Peat, Marwick, Mitchell \& Co., 727 F.2d 873, 879 (9th Cir.) (reaching a similar conclusion in an action against a certified public accountant), cert. denied, 496 U.S. 932 (1984); O'Bear, $840 \mathrm{~F}$. Supp. at 1284 ("The doctrine has been extended to apply even where the defendant does not dominate, or even sit on, the relevant entity's board."); Gardner, $798 \mathrm{~F}$. Supp. at 795 ("[D]efendant attempts to unduly restrict the reach of the adverse domination doctrine. Contrary to defendant's contention, the doctrine has been applied in cases involving defendants who were neither officers nor directors of the corporation.").

${ }_{97}$ See, e.g., Federal Deposit Ins. Corp. v. Shrader \& York, 991 F.2d 216, 227 (5th Cir. 1993) (noting that the doctrine does not apply to third parties under Texas law), cert. denied, 114 S. Ct. 2704 (1994).

${ }^{98}$ See, e.g., Resolution Trust Corp. v. Farmer, 865 F. Supp. 1143, 1157 (E.D. Pa. 1994) (placing the burden on the plaintiff to prove that an informed person could not have induced the corporation to sue).

${ }_{99}^{99} 635$ A.2d 394 (Md. 1994).

${ }^{100} \mathrm{Id}$. at 401-02 (stating that the disinterested majority test "provides that claims by a corporation do not accrue and/or limitations do not run against any of the culpable officers and directors until there exists a disinterested majority of nonculpable directors").

${ }^{101}$ See id. at 407-08 (noting that the doctrine carries a presumption in favor of plaintiffs that a corporation will not sue as long as a majority of the board is culpable).

${ }^{102}$ See id. (noting that directors control resources and information).

${ }^{103}$ See id. at 407 (noting that the presumption "could be rebutted ... if [the defendants] could show that the ... . disinterested directors could have brought suit against them"); see also Resolution Trust Corp. v. Scaletty, No. 72,230, 1995 WL 111986 , at *3 (Kan. Mar. 17, 1995) (" $[\mathrm{T}]$ he plaintiff enjoys a presumption that the course [sic] of action does not accrue so long as the culpable directors remain in the 
some, ${ }^{104}$ the allocation of the burden of proof does not turn on whether adverse domination is seen as a tolling or an accrual doctrine. ${ }^{105}$ The resolution of the burden of proof issue is of key importance because courts need to know how to apply the adverse domination doctrine.

Courts disagree about the resolution of the boundaries of adverse domination because they are unsure of the theoretical underpinnings of the doctrine. ${ }^{106}$ The resolution of these issues necessarily depends on whether the doctrine is based on principles akin to fraudulent concealment theory (estoppel principles based on the conduct of the defendant) or on principles akin to the discovery rule (principles based on fairness to the plaintiff in not barring claims that are inherently unknowable). The next Part of this Comment will resolve these inconsistencies by determining the theory behind the adverse domination doctrine.

\section{The Proper Theoretical Basis of the AdVERSE DOMINATION DOCTRINE: THE DISCOVERY RULE}

Given the confused state of the law surrounding the adverse domination doctrine, it is important to discern the theoretically correct application of the doctrine. Thus, as state supreme courts adopt the doctrine, they can do so in a consistent manner. This

majority.").

${ }^{104}$ See Fields, supra note 83, at 162-63 (arguing that whether adverse domination is looked at as a tolling doctrine or an accrual doctrine will change the allocation of the burden of proof).

105 The courts in both Hecht v. Resolution Trust Corp., 635 A.2d 394 (Md. 1994), and Resolution Trust Corp. v. Farmer, 865 F. Supp. 1143 (E.D. Pa. 1994), found adverse domination to be a variant of the discovery rule, an accrual doctrine. See infra notes 128-33 and accompanying text. The Hecht court placed the burden of proof on the defendant, see supra note 101, whereas the Farmer court placed the burden on the plaintiff. See supra note 98.

${ }^{106}$ See Federal Deposit Ins. Corp. v. Bird, 516 F. Supp. 647, 651 (D.P.R. 1981).

The Bird court noted that the cases involving adverse domination

rely on various theories, e.g., that control per se precludes the possibility of filing suit, that control puts the corporation in the position of a cestui of a trust and unable to make an adverse claim, or that control relates to a concealment or nondisclosure, fraudulent or otherwise, of the existence of grounds for a cause of action.

Id. 
Part will explore the theoretical basis of the adverse domination doctrine. First, the doctrine will be analyzed under the rubric of the fraudulent concealment rule. Although adverse domination shares certain similar aspects with fraudulent concealment, this is not the most satisfactory mode of analysis. An analysis of adverse domination under the rubric of the discovery rule will illustrate that it is the inherently unknowable nature of the harm that is essential to adverse domination. Thus, the discovery rule is the better model by which to analyze the adverse domination doctrine.

\section{A. Adverse Domination as Fraudulent Concealment}

Fraudulent concealment tolls the statute of limitations based on principles related to the conduct of the defendant-the defendant must have in some way affirmatively concealed from the plaintiff that a cause of action exists. ${ }^{107}$ In the case of a corporation, the question is complicated by the fact that the corporation is a fictional entity that can act only through its directors. ${ }^{108}$ With the exception of shareholder derivative suits, ${ }^{109}$ directors are the only ones who can bring suit for the corporation. ${ }^{110}$ Therefore, if the

${ }^{107}$ See supra notes 34-41 and accompanying text.

${ }^{108}$ See Resolution Trust Corp. v. Farmer, 865 F. Supp. 1143, 1151 (E.D. Pa. 1994) (noting that a corporation can act only through its directors); In re Maxwell Newspapers, Inc., 164 B.R. 858, 866 (Bankr. S.D.N.Y. 1994) ("In the case of a corporation, which can act only through its agents, the rule is that the actions of corporate directors and officers are attributable to the corporate entity."); MODEL BUSINESS CORP. ACT § 8.01(b) (1984 \& Supp. 1991) ("All corporate powers shall be exercised by or under the authority of, and the business and affairs of the corporation managed under the direction of, its board of directors . . . .); 1 KNEPPER \& BAILEY, supra note $90, \S 1-2$, at 4 ("Most state corporation statutes provide that the business and affairs of a corporation shall be managed by or under the direction of its board of directors.").

${ }^{109}$ See infra part III.C (resolving the problem of derivative suits in the discovery rule context).

${ }^{110}$ The general rule is that the board of directors is the party charged with bringing suit for the corporation, because this act involves the business operations of the board. See Bird, 516 F. Supp. at 651 (stating that the board of directors is the group in which the corporation "entrusted the discretion to sue"); Hecht v. Resolution Trust Corp., 635 A.2d 394, 398 (Md. 1994) ("Maryland law provides that directors of a corporation exercise all powers of the corporation ... [including the power to sue]."); MODEL BUSINESS CORP. ACT \& 8.01(b) (providing that the board shall manage the business of the corporation). A shareholder may also bring an action against the board on behalf of the corporation in the form of a derivative suit. The difficulty with pursuing such an action due to heightened pleading requirements, however, means that the possibility of shareholder derivative actions does not destroy the discovery rule as a theoretically sound basis for the adverse domination doctrine. See infra part III.C. 
dominating directors are attempting to conceal the corporation's cause of action, it must be an attempt to conceal it from the nonculpable directors of the corporation. Thus, if adverse domination is analyzed through the lens of fraudulent concealment, domination of the corporation is characterized as influential complete domination: the dominating directors are using their influence over the board to keep it from bringing suit against them. ${ }^{111}$

Adverse domination certainly has some aspects that liken it to fraudulent concealment. Whenever a court uses language like "where culpable directors and officers control a corporation, they are unlikely to initiate actions or investigations for fear that such actions will reveal their own wrongdoing," that court is at least partially concerned with the conduct of the defendant in preventing a suit from being brought, rather than with the unfairness to the plaintiff. ${ }^{112}$

Although adverse domination does have some elements similar to fraudulent concealment, there are several factors that make fraudulent concealment an unsatisfactory mode of analysis. First,

${ }^{11}$ In International Rys. of Cent. Am. v. United Fruit Co., 373 F.2d 408 (2d Cir.), cert. denied, 387 U.S. 921 (1967), the court noted that prior decisions were unable to clarify whether the adverse domination doctrine was being invoked "as affecting the ability to sue [or] ... as effecting concealment." Id. at 414 . But the court seemed to indicate that the cases generally require at least a majority of culpable directors to toll the statute of limitations under the doctrine, see id., which indicates that the court was actually basing its outcome on numerical complete domination. Other courts have not yet distinguished carefully between whether adverse domination is being applied because of the influence the directors have used over the other directors or because of the power gained by majority control. At least some courts have implied in their language, however, that influence is a factor. See Resolution Trust Corp. v. Thomas, 837 F. Supp. 354, 359 (D. Kan. 1993) (finding that adverse domination was possible with less than a majority of culpable directors when the one culpable director was the sole shareholder, suggesting that his influence was the significant issue). In Resolution Trust Corp. v. Gardner, 798 F. Supp. 790 (D.D.C. 1992), the court applied adverse domination against a third party who was involved with the director's wrongdoing. See id. at 795. This outcome suggests that even a nondirector can exercise influential domination over a corporation. See Hanna, supra note 61 , at 653 ("A majority of the cases ... have accepted that attorneys can exercise domination of an institution ....").

${ }^{112}$ Gardner, 798 F. Supp. at 795; see also Resolution Trust Corp. v. O'Bear, Overholser, Smith \& Huffer, 840 F. Supp. 1270, 1284 (N.D. Ind. 1993) ("The rationale behind the adverse domination doctrine is premised upon the principle that officers and directors who have harmed the entity cannot be expected to take legal action against themselves." (citation omitted)); Hanna, supra note 61, at 653-54 (noting that adverse domination is justified because officers are unlikely to sue themselves); Leslie, supra note 11, at 1595 (same). 
if adverse domination is treated as having its roots in the influence effect, the corporation would need to prove active concealment by the dominating directors. ${ }^{113}$ If the corporation can prove active concealment, however, it already has a strong case for simply applying the traditional fraudulent concealment rule. In other words, the fact that the dominating directors are using their influence to inhibit suit means that they are actively using their influence to force the other directors not to sue and are thus engaged in fraudulent concealment. ${ }^{114}$ Thus, a theory of adverse domination would really serve no purpose-it would, in fact, be identical to fraudulent concealment. Indeed, the Fourth Circuit seems to have accepted this interpretation of the adverse domination doctrine. ${ }^{115}$

One could argue that a claim of adverse domination could serve the purpose of creating a presumption that the cause of action was fraudulently concealed, thereby placing the burden on the defendant to prove that there was no fraudulent concealment. To a certain extent this scheme is very plausible. It seems reasonable to create a rebuttable presumption that someone committing some affirmative misconduct, such as stealing from the corporation, would conceal her conduct from the other directors. In cases involving fraud committed by the directors, however, the presumption probably would not be that important. Many jurisdictions, as well as federal common law, do not require additional fraudulent concealment when the underlying cause of action is fraud, granting tolling not only for "fraudulent concealment" but also for "undiscovered fraud."116 Therefore, proving fraudulent concealment in

${ }^{113}$ See Federal Deposit Ins. Corp. v. Cocke, 7 F.3d 396, 402 (4th Cir. 1993) (holding that under Virginia's fraudulent concealment law "a statute of limitations is tolled until a person intentionally misled by a putative defendant could reasonably discover the wrongdoing" (emphasis added)), cert. denied, $115 \mathrm{~S}$. Ct. 53 (1994); supra notes $34-45$ and accompanying text (noting that fraudulent concealment usually requires active concealment).

${ }^{114}$ Even if the directors are not actively concealing, there is recent authority suggesting that active concealment is not required in cases involving a fiduciary duty. See supra note 37.

${ }^{115}$ See Cocke, 7 F.3d at 402 (relating the adverse domination doctrine to fraudulent concealment under a Virginia statute); see also Resolution Trust Corp. v. Walde, 856 F. Supp. 281, 286 (E.D. Va. 1994) (comparing adverse domination to fraudulent concealment); Resolution Trust Corp. v. Everhart, 837 F. Supp. 155, 158 (E.D. Va. 1993) (same), aff'd, 37 F.3d 151 (4th Cir. 1994).

${ }^{116}$ See Dawson, supra note 37, at 880; Leslie, supra note 11, at 1593-94; Note, supra note 3 , at 854 . 
fraud cases would not require affirmative misrepresentation, and the rebuttable presumption would not be needed.

After intentional torts are removed by the undiscovered fraud rule, the rebuttable presumption would remain for cases in which there is no scienter. Greating a presumption of concealment does not seem to make a lot of sense in cases involving negligence or gross negligence. Although a board of directors may choose not to pursue a negligence claim against themselves, this does not necessarily mean they are fraudulently concealing the cause of action from the corporation or from each other. Indeed, given the lack of scienter in these cases, it is perfectly reasonable to believe that the director may feel she is innocent and that pursuit of the action would not be in the best interests of the corporation. ${ }^{117}$

Another problem with analyzing adverse domination along the lines of fraudulent concealment is that the dominating directors do not need to conceal the corporation's cause of action. Almost all adverse domination cases require the board to be composed of at least a majority of culpable directors. ${ }^{118}$ If the dominating directors completely dominate the board, there are no independent directors from whom to conceal the cause of action. Even if the dominating directors control only a majority of the board, the board of directors must act through majority rule, and the directors do not need to conceal their actions from the other directors if they have a majority that will vote against bringing suit. ${ }^{119}$ The only parties

${ }^{117}$ Delaware case law, by applying the business judgment rule to the decision not to bring a lawsuit, creates a presumption that directors act in good faith, even when they are dominated. See Aronson v. Lewis, 473 A.2d 805, 818 (Del. 1984) (holding that demand is not excused simply because the board would have to sue itself; facts must be alleged with particularity in order to overcome the business judgment rule); Paul H. Dawes \& Mary E. Kostel, The Treatment of the Demand Requirement and the Use of the Special Litigation Committee in Delaware Law and in the American Law Institute's "Principles of Corporate Governance: Analysis and Recommendations," in SECURITIES LIIIGATION 1992, at 383, 389 (PLI Litig. \& Admin. Practice Course Handbook Series No. 4-444, 1992) (noting the "great deference accorded" to a board's decision not to sue under Delaware law).

${ }^{118}$ See supra notes $83-87$ and accompanying text (asserting that it is generally accepted that, in order to invoke the adverse domination rule, the board must be composed of at least a majority of culpable directors).

${ }^{119}$ If one of the members of the board is able to induce the shareholders to bring a derivative suit, however, there may be reason for the dominating directors to conceal their cause of action. This problem is accounted for by only applying adverse domination when the board is completely dominated. See infra notes 184-89 and accompanying text. Therefore, whether a presumption of fraudulent concealment may be appropriate in negligence cases in which the dominating directors constitute only a majority of the board is beyond the scope of this Comment because such a 
left from whom to conceal the cause of action would be the shareholders. As discussed below, however, the difficulties in bringing a shareholder derivative suit make it largely unnecessary to make affirmative efforts to conceal the cause of action from shareholders. ${ }^{120}$

\section{B. Adverse Domination Is More Similar to the Discovery Rule}

Although adverse domination shares some aspects with fraudulent concealment, it makes more sense to examine the doctrine as a variant of the discovery rule. This section first examines how the theory supporting the discovery rule is very similar to the theory supporting the doctrine of adverse domination. It then discusses recent decisions that reach the conclusion that adverse domination is similar to the discovery rule.

It is a well-settled principle of agency law that when an agent is acting adversely to the interests of the principal, any knowledge gained by that agent will not be imputed to the principal. ${ }^{121}$ In the corporate context, the corporation is the principal, and the board of directors as a whole is the agent. ${ }^{122}$ Therefore, when the board is controlled by a majority of wrongdoers acting adversely to the corporation, ${ }^{123}$ not only is the cause of action difficult to discover,

situation would not be considered adverse domination.

${ }^{120}$ See infra part III.C (outlining the procedural requirements of a shareholder derivative suit).

${ }^{121}$ See In re Maxwell Newspapers, Inc., 164 B.R. 858, 865-68 (Bankr. S.D.N.Y. 1994); Anchor Equities, Ltd. v. Joya, 773 P.2d 1022, 1025 (Ariz. Ct. App. 1989); Resolution Trust Corp. v. Scaletty, No. 72,230, 1995 WL 111986, at *6 (Kan. Mar. 17, 1995); Clark v. Milam, 452 S.E.2d 714, 718 (W. Va. 1994); RESTATEMENT (SECOND) OF AGENCY \& 282 (1958).

${ }^{122}$ Because a director cannot act alone, but only through the board of directors as a whole, it is the board as a whole, and not the individual director, that is the agent of the corporation. See infra note 158 and accompanying text (explaining that a corporation can usually only act through its board of directors).

${ }^{123}$ It should be noted that if the board of directors is accused of breaching its duty to the corporation, it necessarily is accused of acting adversely to the principal's interests. See Resolution Trust Corp. v. Farmer, 865 F. Supp. 1143, 1155-56 (E.D. Pa. 1994) (stating that the knowledge of an agent acting adversely to its principal will not be imputed to the principal in adverse domination situations); Hecht v. Resolution Trust Corp., 635 A.2d 394, 405 (Md. 1994) (same); see also infra note 198 (asserting that negligence meets the adverse interest requirement in the adverse domination context). Indeed, this is the basis of any suit against the directors of a corporation. See, e.g., Smith v. Van Gorkom, 488 A.2d 858, 872 (Del. 1985); see also 1 KNEPPER \& BAIlEY, supra note 90 , $\$ 1-4$, at 9 . 
it is legally impossible for the corporation to gain the knowledge necessary for it to discover its cause of action. ${ }^{124}$

This "inherently unknowable" aspect of the breach of duty by the board unquestionably ties adverse domination to the theoretical underpinnings of the discovery rule. ${ }^{125}$ Although many courts have applied adverse domination with little analysis as to why they were accepting it, ${ }^{126}$ several recent cases have insightfully observed that the doctrine is akin to the discovery rule because adverse domination is also based on the principle of "inherently unknowable harm." ${ }^{127}$

In Resolution Trust Corp. v. Farmer, ${ }^{128}$ Judge Rendell of the Eastern District of Pennsylvania considered whether adverse domination is applicable under Pennsylvania law. Judge Rendell concluded that "the adverse domination doctrine [is] in accord with the essence of Pennsylvania's discovery rule. ${ }^{129}$ She held:

It is the "inherently unknowable" character of the injury that is the critical factor that governs the applicability of the discovery rule. ... A corporate plaintiff does not have "knowledge" of an

124 The fictional nature of the corporate entity makes this concept more difficult to understand, especially because the concept is driven not by tangible logic of the ability of a person to discover, but by principles of agency law. See Resolution Trust Corp. v. O'Bear, Overholser, Smith \& Huffer, 840 F. Supp. 1270, 1284 (N.D. Ind. 1993) ('As a corporate entity, [plaintiff] can only 'discover' an injury to itself, and act to redress that injury, to the extent that those individuals who control it know of the injury and are willing to act on that knowledge."); Beal v. Smith, 189 P. 341, 345 (Cal. Ct. App. 1920) (noting that where a corporation and its board were "wholly under the domination of those who committed the original fraud, the corporation is deemed to be in the same position as an incompetent person or a minor without legal capacity either to know or to act in relation to the fraud so committed"); Clark, 452 S.E.2d at 719 (" [A]s a matter of law, [plaintiff] cannot be deemed to have known of its claims against the $O \&$ D Defendants arising out of the acts they allegedly committed adverse to [the corporation's] interests.").

${ }^{125}$ See supra notes 43.52 and accompanying text (noting that the discovery rule is driven by the unfairness of charging a plaintiff with an inherently unknowable injury).

${ }^{126}$ See, e.g., Resolution Trust Corp. v. Gardner, 798 F. Supp. 790, 794-95 (D.D.C. 1992) (relying heavily on the application of the doctrine by other federal courts).

${ }_{127}$ See, e.g., Farmer, 865 F. Supp. at 1155; Hecht, 635 A.2d at 400; Clark, 452 S.E.2d at 717-18. But see, e.g., Federal Deposit Ins. Corp. v. Cocke, 7 F.3d 396, 402 (4th Cir. 1993) (stating that adverse domination under Virginia law is fraudulent concealment), cert. denied, 115 S. Ct. 53 (1994); Resolution Trust Corp. v. Walde, 856 F. Supp. 281, 286 (E.D. Va. 1994) (noting that adverse domination "tolling theory is not recognized in Virginia"); Resolution Trust Corp. v. Everhart, 837 F. Supp. 155, 158 (E.D. Va. 1993) (finding that, in Virginia, the statute of limitations is not tolled unless the directors concede to their wrongdoing).

${ }^{128} 865$ F. Supp. 1143 (E.D. Pa. 1994).

${ }^{129}$ Id. at 1157 . 
injury to itself until those individuals who control it know of the injury and are willing to act on that knowledge. This idea is consistent with Pennsylvania agency law, which provides that knowledge of an agent whose interests are adverse to the principal cannot be imputed to the principal. ${ }^{130}$

In Hecht v. Resolution Trust Corp., ${ }^{131}$ the Maryland Court of Appeals reached a similar conclusion regarding the origins of the adverse domination doctrine. The court first traced the history of the application of the discovery rule in Maryland, noting that the doctrine is based on "the unfairness inherent in charging a plaintiff with slumbering on rights not reasonably possible to ascertain." 132 The court then accepted adverse domination, based on the difficulty the corporation has in obtaining knowledge of its cause of action:

In an adverse domination situation the agent cannot reasonably be expected to act upon or communicate knowledge of his own wrongdoing to the corporation. Therefore, in most cases, corporate board members and officers control the corporation and constitute an insuperable barrier to a corporation's ability to acquire knowledge and resources necessary to bring suit against the directors and officers.... The discovery rule provides that accrual takes place only when a plaintiff has notice of the existence of a cause of action. The doctrine of adverse domination presumes that actual notice will not be available until the corporate plaintiff is no longer in control of the erring directors. ${ }^{133}$

In Clark v. Milam, ${ }^{134}$ the West Virginia Supreme Court, speaking through the voice of Justice Neely, reached a conclusion similar to that of the Hecht and Farmer courts. The court held that "a corporate plaintiff cannot 'discover' injuries to the corporation caused by those who control the corporation. ${ }^{n 135}$ Using the same agency principals as the Hecht and Farmer courts, the Clark court held that adverse domination applied as a matter of law. ${ }^{136}$ The Supreme Court of Kansas followed suit, adopting the adverse domination rule under a tort limitation statute providing that a cause of action does not accrue until discovery. ${ }^{137}$ The court

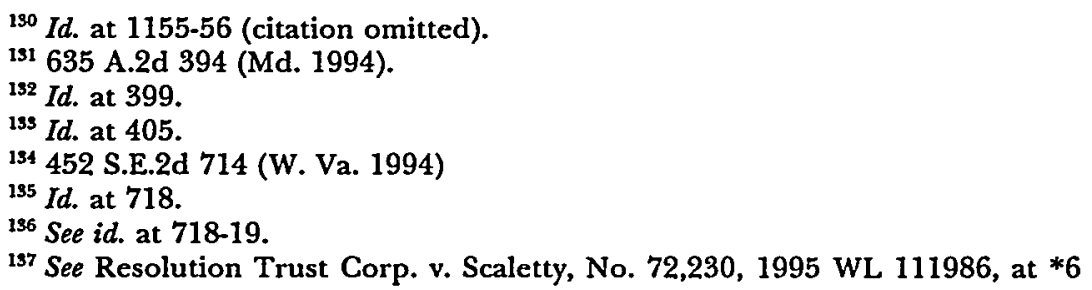


noted that a corporation can act only through its agents, rendering it legally impossible for the corporation to discover its cause of action as long as those directors are in control of the corporation and acting adversely to it. ${ }^{188}$

These cases make it clear that the inherently unknowable nature of the injury drives the doctrine of adverse domination. As such, it is more appropriate to analyze these claims under the rubric of the discovery rule. ${ }^{139}$

\section{Solving the Problem of Derivative Actions}

The possibility of a derivative suit being brought by a sharehold$\mathrm{er}^{140}$ weakens the argument for basing adverse domination on the discovery rule. Although the corporation cannot discover its cause of action because it can acquire information only through its directors, ${ }^{141}$ the same constraint does not necessarily apply to an independent shareholder's ability to discover a cause of action. A shareholder is a human being, capable of using her five senses to gain information by means other than through the board of directors. Therefore, it would seem that the statute of limitations should not be tolled when a shareholder should have discovered the cause of action.

Unfortunately, many courts have glossed over this problem without discussing why derivative actions do not bar the application of the adverse domination doctrine. ${ }^{142}$ Therefore, it is necessary

(Kan. Mar. 17, 1995).

${ }^{139}$ See id. (discussing the agency principles and the difficulties involved when a corporation tries to discover its causes of action).

${ }^{139}$ See Resolution Trust Corp. v. Smith, 872 F. Supp. 805, 813 (D. Or. 1995) ("This court agrees with the Supreme Court of the state of Maryland that the doctrine of adverse domination is a corollary of the discovery rule and determines the accrual of a cause of action ...."); Resolution Trust Corp. v. O'Bear, Overholser, Smith \& Huffer, 840 F.Supp. 1270, 1284 (N.D. Ind. 1993) (relating adverse domination almost exactly to the discovery rule, and holding that "a corporate 'plaintiff' has not discovered alleged negligence until that negligence is discovered by those who can be expected to act to redress the entity's interest $\left.{ }^{n}\right)$. But see Resolution Trust Corp. v. Bright, 872 F. Supp. 1551, 1568 (N.D. Tex. 1995) (confusing the application of the discovery rule by searching for discovery by the board, rather than by the corporation as an entity); $i d$. at $1565-71$ (attempting to analyze the statute of limitations problems under adverse domination, the discovery rule, and fraudulent concealment).

${ }^{140}$ A derivative action is an action brought by a shareholder to enforce the rights of the corporation. See BLACK'S LAW DICTIONARY 443-44 (6th ed. 1990); 2 KNEPPER \& BAILEY, supra note $90, \S 18-1$ (c), at 112-13 (discussing derivative suits generally). ${ }^{141}$ See supra note 108 and accompanying text.

${ }^{142}$ Some cases have discussed derivative suits but have not analyzed the problem 
to explain briefly why derivative actions do not pose a problem for basing the adverse domination theory on the discovery rule. This explanation is based on two factors: the reality of the business judgment rule and the rules of civil procedure.

A shareholder who wishes to bring a suit on the corporation's behalf must almost always first make a demand upon the corporate board of directors to sue. ${ }^{143}$ If the board of directors is asked to bring suit and refuses, that decision is subject to the business judgment rule and is voidable only if made in bad faith. ${ }^{144} \mathrm{Al}-$ though the shareholder can allege that the board's decision was not in good faith because it was adversely dominated, most courts will require that this allegation be pled with specificity. ${ }^{145}$

in any depth. See International Rys. of Cent. Am. v. United Fruit Co., 373 F.2d 408, 412 (2d Cir.) (recognizing that "once the facts giving rise to the action have become known to independent directors ... they can bring a derivative action"), cert. denied, 387 U.S. 921 (1967); Federal Deposit Ins. Corp. v. Brown, No. CIV.A.H-91-2073, 1992 WL 677891, at *2 (S.D. Tex. Dec. 3, 1992) (applying the adverse domination doctrine despite the defendants' contention that it should not apply because the majority shareholder could have brought a derivative suit); Hecht v. Resolution Trust Corp., 635 A.2d 394, 407-08 (Md. 1994) (briefly discussing the possibility of a derivative action).

${ }^{143}$ See Zapata Corp. v. Maldonado, 430 A.2d 779, 784 (Del. 1981) (indicating circumstances when the demand requirement is excused); Note, Discovery in Federal Demand-Refused Derivative Litigation, 105 HARv. L. REv. 1025, 1095-26 (1992) ("Because of the various costs associated with derivative actions, all states require shareholders first to 'demand' action from the corporation's directors."); $c f$. Aronson v. Lewis, 473 A.2d 805, 814 (Del. 1984) (tightening the demand requirement considerably).

${ }^{144}$ See Aronson, $473 \mathrm{~A} .2 \mathrm{~d}$ at 812 (stating that the business judgment rule "is a presumption that in making a business decision the directors of a corporation acted on an informed basis, in good faith and in the honest belief that the action taken was in the best interests of the company"); see also Zapata, $430 \mathrm{~A} .2 \mathrm{~d}$ at 784 ("[A] board decision to cause a derivative suit to be dismissed as detrimental to the company, after demand has been made and refused, will be respected unless it was wrongful."); Dawes \& Kostel, supra note 117, at 393 (explaining that to plead wrongful rejection the plaintiff must show that either the directors were interested or the board was grossly negligent); Note, supra note 143, at 1026 ("Many states allow corporations to terminate 'demand-refused' derivative suits unless shareholders can provide some evidence that the corporate directors wrongfully refused the shareholders' demand."); cf. Joel Seligman, The Disinterested Person: An Alternative Approach to Shareholder Derivative Litigation, 55 LAW \& CONTEMP. PROBS. 357, 360-61 (1992) (discussing the ability of a special litigation committee to dismiss an action).

${ }^{145}$ See Dawes \& Kostel, supra note 117, at 393 ("A successful showing of interestedness, while less rare, requires plaintiff to demonstrate with particular facts that the director(s) in question had a special pecuniary interest in the transaction."); Note, supra note 143, at 1028 ("Some federal courts have held that rule 23.1 requires plaintiffs to demonstrate wrongful refusal solely through the pleadings ...."). 
Another option for the shareholder is to attempt to avoid the demand requirement altogether by claiming that demand would be futile. The shareholder must plead with specificity, however, in accordance with Federal Rule of Civil Procedure 23.1 or the equivalent state rule, why the board is not independent and capable of making a fair decision about whether suit should be brought. ${ }^{146}$ The Delaware Supreme Court, in Aronson v. Lewis, ${ }^{147}$ has enforced this requirement even when the board was dominated by a majority of directors:

[I]n the demand context even proof of majority ownership of a company does not strip the directors of the presumptions of independence, and that their acts have been taken in good faith and in the best interests of the corporation. There must be coupled with the allegation of control such facts as would demonstrate that through personal or other relationships the directors are beholden to the controlling person....

....

We conclude that in the demand-futile context a plaintiff charging domination and control of one or more directors must allege particularized facts manifesting a "direction of corporate

${ }^{146}$ Federal Rule of Civil Procedure 23.1 provides, in relevant part:

In a derivative action brought by one or more shareholders or members to enforce a right of a corporation or of an unincorporated association, the corporation or association having failed to enforce a right which may properly be asserted by it, the complaint shall be verified and shall allege ... with particularity the efforts, if any, made by the plaintiff to obtain the action the plaintiff desires from the directors or comparable authority and, if necessary, from the shareholders or members, and the reasons for the plaintiff's failure to obtain the action or for not making the effort.

FED R. Crv. P. 23.1. Delaware's derivative rule is essentially the same. See DEL. CH. CT. R. 23.1.

The Delaware Supreme Court has held that "the entire question of demand futility is inextricably bound to issues of business judgment and the standards of that doctrine's applicability." Aronson, 473 A.2d at 812. Concerned that after Zapata shareholders were filing too many derivative suits alleging demand futility, the court also held:

The Court of Chancery in the exercise of its sound discretion must be satisfied that a plaintiff has alleged facts with particularity which, taken as true, support a reasonable doubt that the challenged transaction was the product of a valid exercise of business judgment. Only in that context is demand excused.

Id. at 815; see also Note, supra note 143, at 1027 ("Federal courts have generally agreed that rule 23.1 requires plaintiffs who claim demand futility to plead specific facts to support their claim." (footnote omitted)).

14773 A.2d 805 (Del. 1984). 
conduct in such a way as to comport with the wishes or interests of the corporation (or persons) doing the controlling." 148

The Aronson court went on to hold that even if all of the directors are named in the suit and therefore subject to potential liability, facts must be alleged with particularity such that Rule 23.1 is not abrogated and managerial powers of directors are not weakened. ${ }^{149}$

Therefore, the shareholder must be able to plead with specificity to either attack a board's decision not to sue or circumvent the demand requirement. Unfortunately, such pleadings must be prepared without the benefit of discovery. ${ }^{150}$ Without discovery, making the required showing of specificity to overcome the business judgment rule or the demand-excused requirement is an almost insurmountable barrier to a shareholder derivative suit. ${ }^{151}$ This result is especially likely when the board is completely dominated by the alleged wrongdoers, because they are unlikely to be helpful in providing the shareholders with information. ${ }^{152}$

${ }^{148} I d$. at 815-16 (citations omitted).

149 See id. at 818.

${ }^{150}$ See Levine v. Smith, 591 A.2d 194, 209 (Del. 1991) (not allowing discovery in a demand-refused case). See generally Note, supra note 143 (arguing that discovery should be allowed before derivative suits are dismissed on the pleadings because the plaintiff otherwise has no meaningful possibility of winning even a meritorious suit).

${ }^{151}$ See Note, supra note 143, at 1028-29. The difficulty for shareholders is apparent:

[S]ome ... courts have forced shareholders to present evidence of a wrongful refusal without the benefit of discovery, even though it is difficult for shareholders who have no information about a corporation's investigatory procedures to create a reasonable doubt that a corporation adequately investigated a demand. Such decisions create a virtually insurmountable obstacle for shareholders who have no knowledge of the internal corporate decisionmaking process and will effectively bar many derivative suits regardless of their merit.

Id. (citations omitted).

152 See Federal Deposit Ins. Corp. v. Brown, No.CIV.A.H-91-2073, 1992 WL 677891 , at $* 2$ (S.D. Tex. Dec. 3, 1992) ("While the alleged wrongdoers remain in control 'they can dominate the non-culpable directors and control the most likely sources of information and funding necessary to pursue the rights of the association." (citation omitted)).

In fact, the refusal to give information may not be accompanied by any fraudulent concealment or wrongdoing on the part of the directors; the board may truly believe that the case is frivolous and that aiding the shareholder in her suit would not be in the best interests of the corporation. See Hecht v. Resolution Trust Corp., 635 A.2d 394, 406 (Md. 1994) ("[S]ituations [exist] other than those which involve fraud where a corporation can be blamelessly unaware of a potential claim against directors and officers. Indeed, the directors and officers may be so disengaged from their responsibilities that they themselves are unaware of the breach 
Given the heavy burden placed on a shareholder in pursuing a derivative claim against a dominated board and the unlikelihood of maintaining such an action, some form of the adverse domination doctrine should still apply. As will be discussed later, however, the possibility of a derivative suit should influence the appropriate level of domination that will be required to invoke the doctrine. ${ }^{153}$

\section{Proper Boundaries of the Adverse Domination Doctrine AS ANALYZED UNDER THE DisCOVERY RULE}

Because adverse domination is essentially a variant of the discovery rule, it seems appropriate that the doctrine should be applied in a manner similar to the application of the discovery rule. Although many courts recognize this analogy, confusion regarding the proper boundaries of the adverse domination doctrine still exists. This Part looks at the four major boundaries of the doctrine that delineate its applicability: the required level of domination, the required level of culpability, the doctrine's application to third parties, and the party upon which the burden of proof should be placed. From a discussion of each of these boundaries, a formulation of the adverse domination doctrine will be extracted that is logically consistent with the principles of the discovery rule.

\section{A. The Required Level of Domination}

\section{Micro-Domination and Macro-Domination}

Domination of a board of directors by one or more dominating directors has long affected the interpretation of corporate law. ${ }^{154}$ Two types of domination can be identified: micro-domination and macro-domination. ${ }^{155}$

Micro-domination occurs when one or more directors have influence and power over the other directors to the extent that they

of their duty to the corporation.").

${ }^{153}$ See infra notes $171-73,185-86$ and accompanying text.

154 See, e.g., Fowle Memorial Hosp. Co. v. Nicholson, 126 S.E. 94,97 (N.C. 1925) (refusing to give validity to a board's approval of a lease between the corporation and a dominating director); Lutherland, Inc. v. Dahlen, 53 A.2d 143, 145, 147 (Pa. 1947) (refusing to sustain an action of the person who "largely dominated the Board of Directors"); see also supra notes 2-3 and accompanying text (discussing the theory that a dominated board prevents a corporation from taking action against dominating directors).

${ }^{153}$ These terms have not been advanced in the literature previously. Dividing domination into these categories is useful for an analysis of adverse domination. 
are considered "dominating directors" or "dominating shareholders." ${ }^{156}$ This type of domination refers only to the influence of one or two directors over the other directors. A dominant director or shareholder interferes with the normal democratic interchange among members of the board. ${ }^{157}$ A board of directors generally must act as a unit, ${ }^{158}$ and when one director has the power to influence or control the board, that director is taking for herself the power that ordinarily belongs to the board as a whole. Microdomination is exclusively concerned with the influence of the dominating directors over the other members of the board.

The other type of domination, macro-domination, arises when the board is controlled by a majority of directors who impose their will on the corporation through their voting control on the board. Here the domination is not by one or two directors over the other board members; instead, the domination is by a majority of the board over the decisions of the corporation. ${ }^{159}$ Macro-domination

${ }^{156}$ See Kahn v. Lynch Communication Sys., Inc., 638 A.2d 1110, 1115 (Del. 1994) (finding domination by a nonmajority stockholder when the "directors deferred to [the stockholder] because of its position as a significant stockholder and not because they decided in the exercise of their own business judgment that [the stockholder's] position was correct" (citation omitted)); Citron v. Fairchild Camera \& Instrument Corp., 569 A.2d 53, 70 (Del. 1989) ("For a dominating relationship to exist in the absence of controlling stock ownership, a plaintiff must allege domination by a minority shareholder through actual control of corporate conduct." (citations omitted)); see also Charles Hansen et al., The Role of Disinterested Directors in "Conflict" Transactions: The ALI Corporate Governance Project and Existing Law, 45 BUS. LAw. 2083, 2099-100 (1990) (explaining that, under $\S 5.10$ of the ALI's Principles of Corporate Governance, a 25\% stockholder is considered a "dominating stockholder," which has the effect of imposing upon minority shareholders fiduciary duties traditionally required only of dominating stockholders).

${ }^{157}$ See Levine v. Smith, 591 A.2d 194, 205 (Del. 1991) ("When lack of independence is charged, a plaintiff must show that the Board is either dominated by an officer or director who is the proponent of the challenged transaction or that the Board is so under his influence that its discretion is 'sterilize[d]." (citations omitted)); 1 KNEPPER \& BAILEY, supra note $90, \S 4-21$, at 172 ("The desires of such a [dominating] director obviate the interplay of diverse judgments among several members of the board." (citation omitted)).

${ }^{158}$ See Hurley v. Ornsteen, 42 N.E.2d 273, $275-76$ (Mass. 1942) (noting that in certain circumstances a majority may bind a board without a meeting, but some type of affirmative approval is required by all directors); Baldwin v. Canfield, 1 N.W.261, 270 (Minn.) ("[Directors] have no authority to act [for the corporation], save when assembled at a board meeting."), modified, 1 N.W. 276 (Minn. 1879); MODEL BUSINESS CORP. ACT $\$ 8.21$ (1984) (stating that directors can bind a corporation without a meeting only if the action is "taken by all members of the board" and evidenced by "written consents"); 1 KNEPPER \& BAILEY, supra note 90, § 4-21, at 172 ("The authority of the directors is conferred upon them as a board, their action is expected to be taken as a group and not individually ....").

${ }^{159}$ See Resolution Trust Corp. v. Fleischer, 826 F. Supp. 1273, 1276 (D. Kan. 1993) 
is determined by the numerical power of board members to control the corporation by majority vote. Influential control is irrelevant as long as the dominating majority has a single viewpoint.

\section{Adverse Domination Is a Form of Macro-Domination}

Macro-domination affects the agent-principal relationship between the board and the corporation. Because a corporation can act only by majority vote, the actions of the board will not be imputed to the principal corporation if the dominating majority is acting adversely to the principal. ${ }^{160}$ Because the discovery rule drives the adverse domination doctrine, the inquiry turns on numerical control of the board ${ }^{161}$ and, thus, macro-domination. If micro-domination were enough to support a claim of adverse domination, however, courts would have to look to the influence of domination on the corporation's ability to bring suit. This result would be analogous to fraudulent concealment because such an inquiry would focus on the behavior of the defendant in preventing the plaintiff from asserting a cause of action.

\section{The Required Level of Numerosity}

Although it is generally accepted that macro-domination is required for adverse domination to apply, it remains unclear what level of macro-domination is required. This section will discuss the appropriate level of macro-domination by first analyzing the problems at the extreme ends of the continuum. This section will then show that the more appropriate test can be found in the

(noting that adverse domination results when directors charged with wrongful conduct dominate a corporation such that the corporation itself is unable to gain information about the activities of the directors); Resolution Trust Corp. v. Gardner, 798 F. Supp. 790, 795 (D.D.C. 1992) (" [W] here culpable directors and officers control a corporation, they are unlikely to initiate actions or investigations for fear that such actions will reveal their own wrongdoing."); Federal Deposit Ins. Corp. v. Hudson, 673 F. Supp. 1039, 1042 (D. Kan. 1987) (explaining that a corporation cannot bring suit against its directors as long as those directors control the affairs of the corporation); Leslie, supra note 11, at 1595 (noting that directors dominating a corporation can effectively prevent the corporation from bringing suit "because wrongdoers cannot be expected to initiate a cause of action against themselves").

${ }^{160}$ See supra notes 121-24 and accompanying text (discussing the imputation of knowledge).

${ }^{161}$ See Resolution Trust Corp. v. Bright, 872 F. Supp. 1551, 1565 (N.D. Tex. 1995) (stating that the presence of adverse domination is determined by a numerical test); supra notes 121-24 and accompanying text (noting that a corporation acts through majority rule and thus the majority is the agent of the corporation). 
middle of the continuum.

At the lower end of the macro-domination scale would be macro-domination in which the dominating directors would consist of only a simple majority of the culpable directors. ${ }^{162}$ The Fifth Circuit, in Federal Deposit Insurance Corp. v. Dawson, ${ }^{163}$ held that the FDIC "must show only that a majority of the board members were wrongdoers during period [sic] the plaintiff seeks to toll the statute." 164 Under this formulation of the majority test, once the plaintiff has shown that the corporation is governed by a board of directors, the majority of whom are culpable, the statute of limitations is tolled against them per se, provided the culpability requirement is met. In Dawson, a majority of the directors controlled the board; therefore, the court reasoned, the other directors were powerless to stop them. ${ }^{165}$

In Hecht v. Resolution Trust Corp. ${ }^{166}$ the Maryland Court of Appeals applied what it termed the "disinterested majority" test. ${ }^{167}$ This test states that, until a disinterested majority takes control of the board, the corporation is entitled to a presumption that it cannot discover its cause of action. ${ }^{168}$ The burden is placed on the defendant to rebut the presumption by "showing that there was someone who had the knowledge, ability and motivation to bring suit during the period in which defendants controlled the corporation." ${ }^{169}$ Thus, this is not a per se test. The rationale used by the Hecht court for placing the burden on the defendant was that culpable directors "have greater access to relevant information, and it is more probable that no one else was in the position to bring suit." 170

The main problem with any formulation of the majority test is that it ignores the possibility of a shareholder derivative action. ${ }^{171}$ Disinterested directors in a numerically controlled board cannot

${ }^{162}$ See supra notes 83-87 and accompanying text (explaining the majority requirement to show domination).

${ }^{163} 4$ F.3d 1303 (5th Cir. 1993), cert. denied, 114 S. Ct. 2673 (1994).

${ }^{164} I d$. at 1310.

${ }^{165}$ See id. (quoting Federal Sav. \& Loan Ass'n v. Williams, 599 F. Supp. 1184, 1193 94 n.12 (D. Md. 1984)).

166635 A.2d 394 (Md. 1994).

${ }^{167}$ See id. at 406.

${ }^{168}$ See id. at 406-07.

${ }^{169} \mathrm{Id}$. at 408 .

${ }^{170} \mathrm{Id}$.

${ }^{171}$ See supra part III.C (discussing the dilemma of using the theory of adverse domination when a suit is brought by shareholders on behalf of the corporation). 
force the board of directors to sue. They can, however, reveal the necessary information to shareholders and encourage them to sue or use the information to institute a suit themselves on behalf of the corporation. Such information revealed from an insider should make it possible for the shareholders to plead with the necessary specificity. ${ }^{172}$ This in turn would allow the derivative plaintiffs to obtain discovery, ${ }^{173}$ thereby allowing the suit to proceed within the statutory period.

At the other end of the scale is a rule that forbids application of the adverse domination doctrine unless the plaintiff proves that every member of the board was involved in the domination-that the board was completely numerically dominated. ${ }^{174}$ Unless the plaintiff proves that the board was completely dominated, adverse domination would not apply as a matter of law.

Although the complete domination test resolves the inherent tension of the possibility of a derivative suit, it has its own theoretical failings. In general, the discovery rule does not require that it be absolutely impossible for a plaintiff to discover her cause of action. Instead, the discovery rule requires only that it be so difficult to discover the cause of action that a plaintiff exercising reasonable diligence could not do so. ${ }^{175}$ If complete domination were required to invoke adverse domination, it would be the same as saying that it must be impossible to discover the cause of action before the statute of limitations can be tolled. In reality this would

\footnotetext{
${ }^{172}$ See supra notes 143-52 and accompanying text (discussing the difficulties in bringing a derivative suit).

${ }^{173}$ See supra notes 150-52 and accompanying text (discussing the difficulty in obtaining discovery).

${ }^{174}$ This interpretation comes from the language in International Railways of Central America v. United Fruit Co., 373 F.2d 408, 414 (2d Cir.) ("[A] plaintiff who seeks to toll the statute on the basis of domination of a corporation has the burden of showing 'a full, complete and exclusive control in the directors or officers charged." (quoting Payne v. Ostrus, 50.F.2d 1039, 1042 (8th Cir. 1931)), cert. denied, 387 U.S. 921 (1967). Some commentators have considered this to be the end of the matter-if the plaintiff cannot show complete domination, she loses. See, e.g., Leslie, supra note 11, at 1595. The courts have hedged this interpretation, however, by requiring only that a plaintiff "negate the possibility that an informed stockholder or director could have induced the corporation to sue" in order to show exclusive control. International Rys., $373 \mathrm{~F} .2 \mathrm{~d}$ at 414 . Indeed, the Tenth Circuit, although claiming to apply a complete domination test, applies adverse domination if the plaintiff can show that "an informed director, though capable of suing, would not do so." Farmers \& Merchants Nat'l Bank v. Bryan, 902 F.2d 1520, 1523 (10th Cir. 1990). For further discussion of the development of this strand of the test, see supra notes 73-81 and accompanying text.

${ }^{175}$ See supra note 47 and accompanying text (explaining the discovery rule).
} 
require every single director to be culpable-even those who have no knowledge or are uninformed. This is, of course, logically impossible because an uninformed director could never be culpable. ${ }^{176}$ Allowing adverse domination only when all directors are knowledgeable and culpable would be inconsistent with the underlying principle of the discovery rule and would vitiate the ability of a plaintiff to effectively invoke the adverse domination doctrine in many situations.

Thus, neither extreme level of macro-domination is without its failings. As such, courts have begun to create macro-domination tests that place the required level of numerical control in the middle of the continuum. For example, the court in Resolution Trust Corp. v. Farmer ${ }^{177}$ held that to toll the statute of limitations, the plaintiff must prove that "an informed, empowered, but not culpable person or persons, did not exist from the time the statute of limitations began to run. ${ }^{178}$ This formulation is very similar to the complete domination test; however, it does not require that uninformed directors be culpable. If some directors are uninformed, they will be treated as not being able to encourage a derivative suit.

The court in Clark v. Milam ${ }^{179}$ slightly modified this approach by holding that "the adverse domination doctrine tolls the statute of limitations so long as there is no one who knows of and is able and willing to redress the misconduct of those who are committing the torts against the corporate plaintiff."180 Clark moves further away from the complete domination test by allowing a knowledgeable director to be present as long as the director was one who was not able and willing to sue.

Both Farmer and Clark set the level of macro-domination at a level that avoids theoretical discrepancies with the principles underlying the discovery rule. The cases agree that if the plaintiff can demonstrate that there were no disinterested directors on the board, adverse domination should apply. ${ }^{181}$ This approach cer-

\footnotetext{
${ }^{176}$ For the purposes of this Comment it is assumed that there is no liability for a director who does not know of the injury but should have known.

177865 F. Supp. 1143 (E.D. Pa. 1994).

${ }^{178} I d$. at 1158 (emphasis added).

179452 S.E.2d 714 (W. Va. 1994).

${ }^{180} I d$. at 720 (emphasis added).

${ }^{181}$ See Farmer, 865 F. Supp. at 1157-58 (holding that "the statute will be tolled if there was no informed but not culpable person" (citation omitted)); Clark, 452 S.E.2d at $\mathbf{7 2 0}$ (holding that the statute is tolled until one of the directors is willing to redress the wrong).
} 
tainly makes sense, because if the board contains no disinterested directors, there is neither a majority to bring suit nor a single director to reveal the cause of action to the shareholders. ${ }^{182}$ The cases also agree that if the plaintiff can prove that there was no member of the board of directors who actually knew of the injury, the knowledge should not be imputed to the board or shareholders. ${ }^{183}$

The only disagreement between the two cases is whether the knowledge of a director who knows the corporation has a cause of action but chooses not to inform the shareholders should be imputed to the corporation to start the statute running. ${ }^{184}$ This is a difficult question. Other discovery rule cases provide little guidance because they generally do not involve a multitude of potential plaintiffs who could discover the cause of action and bring suit.

This Comment, however, will show that the better rule is that knowledge of a nonculpable, nondominating director who simply chooses not to bring suit should be imputed to the corporation. First, a director almost certainly will be a shareholder. ${ }^{185}$ Therefore, once she is presented with information, she is capable of bringing a shareholder derivative suit for the corporation. It seems consistent that once a shareholder is capable of suing, but chooses

${ }^{182}$ See supra notes 118-20 and accompanying text (noting that in cases of complete domination, no independent directors remain from whom the cause of action can be concealed).

${ }^{183}$ See Farmer, 865 F. Supp. at 1158 (noting that the plaintiff must prove there are no knowledgeable, nonculpable directors); Clark, 452 S.E.2d at 720 (noting that the plaintiff must prove there is no one knowledgeable of the injury and willing to act on it).

${ }^{184}$ The Farmer court seems to suggest that if a knowledgeable person simply chooses not to act, the statute will run because it requires that the plaintiff prove that "an informed, empowered, but not culpable, person or persons, did not exist." Farmer, 865 F. Supp. at 1158 (emphasis added). Clark is not as clear in its language, but it seems to suggest that the informed directors must be willing to act on that knowledge. See Clark, 452 S.E.2d at 720 (holding that "the adverse domination doctrine tolls the statute of limitations so long as there is no one who knows of and is able and willing to redress the misconduct ${ }^{n}$ ).

${ }^{185}$ Directors may receive stock as part of their compensation. See Corporate Director's Guidebook, 49 BUS. LAW. 1243, 1260 (1994) (noting that "some believe that stock options and restricted stock grants to directors strengthen directors' interest in the overall success of the corporation"). In addition, the federal government has shown its concern that directors of corporations may use their inside information to trade on the shares. See, e.g., Securities Exchange Act of $1934 \$ 16(b), 15$ U.S.C. $\S 78(\mathrm{p})$ (1988) (requiring the "filing of [a] statement of ownership of all securities of issuer by [an] owner of more than ten [percent] of any class of security"). 
not to, the statute must begin to run, regardless whether that particular shareholder is also a director. ${ }^{186}$

Second, and most importantly, the directors who were not culpable originally may become culpable by their failure to act. By failing to divulge the dominating directors' activities, the nondominating directors may become aiders and abetters to the dominating directors' tort. ${ }^{187}$ In these circumstances, it may be appropriate to include these directors in the category of "culpable directors," thereby creating a board that is in fact completely dominated and devoid of nonculpable persons.

The inquiry will, of course, be fact-specific. ${ }^{188}$ Consider the case in which a majority of the board has defrauded one of its creditors. If the nondefrauding directors do not act because they do not believe there is a valid claim in the information or because they do not believe that the directors who committed the violation did so for the purpose of gain, they would probably not be culpable. If, however, they believed the cause to be valid and refused to disclose the information, they may well be culpable. ${ }^{189}$ Thus, the proper

${ }^{186}$ This seems to be an appropriate line to draw. Once a shareholder knows of a cause of action but chooses not to act on it, it seems reasonable that knowledge should be imputed to the corporation. See Clark, 452 S.E.2d at 720 ("If, however, shareholders learn of misconduct that harms their corporation, the discovery rule may no longer toll the limitations period." (citing International Rys. of Cent. Am. v. United Fruit Co., 373 F.2d 408, 414 (2d Cir.), cert. denied, 387 U.S. 921 (1967))).

${ }^{187}$ The best analogy here would probably be aiding and abetting a violation of the rule against insider trading in the case of an insider tipper and an outsider tippee, the scenario in Dirks v. SEC, 463 U.S. 646 (1983). In such a case, the tipper would be the dominating directors and the tippee would be the nondominating directors. Dirks held that the tippee is liable for disclosing inside information when it would be a violation of the tipper's fiduciary duty and the tippee knows that it would be a violation. See id. at 660 . The tippee assumes the tipper's duty in such cases. See id.

Using the same logic as the Dirks court, it could be argued that if the tipper has a duty to disclose rather than a duty to not disclose, and the tippee (nondominator) knows that the tipper (dominator) has this duty, the tippee is aiding and abetting the tipper's fiduciary duty by refusing to disclose the information once the tippee becomes aware of it. Cf. Federal Deposit Ins. Corp. v. Dawson, 4 F.3d 1303, 1312 (5th Cir. 1993) (" $[I] t$ could almost always be said that when one or two directors actively injure the corporation, or profit at the corporation's expense, the remaining directors are at least negligent for failing to exercise 'every precaution or investigation." (quoting International Bankers Life Ins. Co. v. Holloway, 368 S.W.2d 567, 580 (Tex. 1963))), cert. denied, 114 S. Ct. 2673 (1994).

${ }^{188}$ Cf. Dirks, 463 U.S. at 663-64 (a court should look at "objective facts" in determining the purpose of the tipper and the scienter of the tippee).

${ }^{189}$ The Court in Dirks held that it was the tipper's purpose in divulging the information that was relevant. See id. at 662 ("Whether disclosure is a breach of duty therefore depends in large part on the purpose of the disclosure."). If the tippee believes that the tipper has not divulged the information for gain, the tippee generally 
formulation for the domination element of the adverse domination doctrine is for the doctrine to apply when the plaintiff is able to prove that the board of directors was either completely dominated by those charged with having committed the tort or that none of the nondominating directors knew that the cause of action existed. ${ }^{190}$

\section{B. The Required Level of Culpability: Negligence}

The analysis behind the proper level of culpability is much more straightforward. The discovery rule emerged from medical malpractice claims. ${ }^{191}$ Therefore, if the adverse domination doctrine is truly a variant of the discovery rule, it would be illogical to require a culpability requirement greater than negligence. ${ }^{192}$ Nonetheless, many courts require some type of affirmative misconduct because of their concern that the use of the adverse domination doctrine would become too widespread if it were applied to merely negligent conduct. ${ }^{193}$

will not be aiding and abetting. See id.

In accordance with this reasoning, and continuing with the directors analogy, if the nondominating directors do not divulge the information because they believe the dominators have not really done anything wrong, the nondominating directors should be absolved and not considered culpable. If they do not reveal the information when they know that the cause of action is valid, however, they would be aiders and abetters and, therefore, culpable.

190 Whether the doctrine should apply when the nondominating directors have no actual knowledge of the suit, but should have known, is beyond the scope of this Comment. This question, however, may be analyzed under the Dirks rubric. See supra notes $187-89$ and accompanying text.

191 See Heriot, supra note 12, at 955-56 (noting that the discovery rule began with medical malpractice cases, then expanded to legal malpractice and products liability cases); McHugh, supra note 46, at 197 (noting that the modern discovery rule stems from a Pennsylvania Supreme Court case involving a sponge left inside a patient); Diane Kosmach, Note, 25 DEPaUl L. REv. 568, 568-69 (1976) (noting Illinois's expansion of its use of the discovery rule from medical malpractice to other areas of professional malpractice).

${ }^{192}$ For example, the court in Clark v. Milam, 452 S.E.2d 714 (W. Va. 1994), held that the degree of culpability is irrelevant because the reason for tolling the statute of limitations is that the plaintiffs cannot discover the cause of action. See id. at 719.

${ }^{193}$ See, e.g., Resolution Trust Corp. v. Acton, No. 94-10375, 1995 WL 144124, at *5 (5th Cir. April 4, 1995) (noting that because the adverse domination doctrine might be "liberally applied," gross negligence is insufficient to toll the statute); Federal Deposit Ins. Corp. v. Dawson, 4 F.3d 1303, 1312 (5th Cir. 1993) ("If adverse domination theory is not to overthrow the statute of limitations completely in the corporate context, it must be limited to those cases in which the culpable directors have been active participants in wrongdoing or fraud, rather than simply negligent."), cert. denied, 114 S. Ct. 2673 (1994); Resolution Trust Corp. v. Bright, 872 F. Supp. 1551, 1567 (N.D. Tex. 1995) ("Without addressing 'precisely how culpable a majority of directors must be before adverse domination tolling is available,' ... [Dawson] 
The courts are correct in their concerns; however, the potential for such problems occurs whenever the discovery rule is applied, no matter what the context, because most discovery rule cases involve negligence causes of action. ${ }^{194}$ In accordance with this reasoning, the Kansas Supreme Court recently recognized that the culpability required in adverse domination cases must be consistent with that in discovery rule cases. In Resolution Trust Corp. $v$. Scaletty, ${ }^{195}$ the court held that because it had repeatedly delayed accrual of the statute of limitations in other negligence contexts, it would be illogical not to do the same for adverse domination cases. ${ }^{196}$ The court expressed reluctance to change a policy that had been reaffirmed over the years by the courts. ${ }^{197}$ Therefore, if courts are unwilling to apply the adverse domination doctrine to negligence claims, they should be equally unwilling to apply the discovery rule to negligence claims. In other words, based on the historical use of the discovery rule, adverse domination should certainly apply to negligence claims. ${ }^{198}$

nevertheless instructs that Texas courts will not extend adverse domination tolling [when tolling] would risk eliminating the statute of limitations in all cases involving a corporation's claims against its own directors . . . " (quoting Dawson, 4 F.3d at 1313 n.4)); Resolution Trust Corp. v. Farmer, 865 F. Supp. 1143, 1157 (E.D. Pa. 1994) (striking what the judge considered to be a fair balance between the rights of defendants and plaintiffs by requiring a showing that conduct was more culpable than mere negligence).

${ }^{194}$ See supra notes 46-52 and accompanying text (discussing the use of the discovery rule in general contexts and noting negligence-based claims in which the discovery rule was applied).

195 No. 72,230, 1995 WL 111986 (Kan. Mar. 17, 1995).

196 See id. at *8.

197 See id.

${ }^{198}$ It could be argued that the required culpability level is higher than negligence based on agency principles. It is the axiom that knowledge is not imputed to a principal when her agent is acting adversely to her that puts adverse domination in line with the discovery rule. See supra notes $121-27$ and accompanying text (aligning adverse domination to the discovery rule based on agency principles). The Restatement defines "acting adversely" as follows:

The mere fact that the agent's primary interests are not coincident with those of the principal does not prevent the latter from being affected by the knowledge of the agent if the agent is acting for the principal's interests. The rule as stated herein is substantially similar to the rule stated in Sections 235-236, dealing with the liability of a principal or master for the torts of his agent ....

RESTATEMENT (SECOND) OF AGENCY, supra note 121, § $282 \mathrm{cmt}$. c.

The cross references noted in the Restatement comment may lead one to conclude that the agent must be acting outside the scope of her employment to be governed by the adverse interest exception. See id. $\S 235$ (defining conduct outside the scope of employment). Following this line of reasoning would lead to a 


\section{The Adverse Domination Doctrine Is Applicable to Third Parties}

If adverse domination is analyzed as a variant of the discovery rule, corporations should be able to invoke the doctrine to toll the statute of limitations against third parties. Indeed, two of the most recent cases to consider the issue have reached this conclusion. ${ }^{199}$

The logic supporting the conclusion that corporations should be able to invoke the adverse domination doctrine against third parties is quite straightforward. The discovery rule focuses on the disability

conclusion that the agent must be acting in a fraudulent manner in order for the adverse interest exception to apply. See, e.g., Mirror Group Newspapers, PLC v. Maxwell Newspapers, Inc. (In re Maxwell Newspapers, Inc.), 164 B.R. 858, 866 (Bankr. S.D.N.Y. 1994) ('Under the 'adverse interest exception,' when an agent's motive and conduct demonstrate that he has totally abandoned his principal's interest and is acting to defraud his principal, ... his knowledge and misconduct will not be imputed to his principal."). This in turn would allow the discovery rule to drive adverse domination only in these circumstances.

The analogy is incorrect, however, because the adverse interest exception will most often be invoked to vitiate the knowledge of the principal in a claim by a third party. See, e.g., RESTATEMENT (SECOND) OF AGENCY, supra note 121, $\$ 282 \mathrm{cmt}$. a., illus. 1-3; Id. $\S 235 \mathrm{cmt}$. a, illus. 1-3. The same concerns for the rights of innocent third parties, see, e.g., Aiello v. Ed Saxe Real Estate, Inc., 499 A.2d 282, 287 (Pa. 1985) (" $[\mathrm{A}]$ principal is liable to innocent third parties for the . . . torts . . o of his agent."), are not present when the principal is suing her negligent agent directly. See Bostrom v. Jennings, 40 N.W.2d 97, 102 (Mich. 1949) ("[W]hile the negligence of the agent is imputable to the principal making him liable to third parties, it is not imputable to him so as to bar his right to recover from the agent what he has been required to pay as compensation to such third parties."). Thus, although in many contexts some type of affirmative misconduct will be required to invoke the exceptions stated in $\$ 282$ of the Restatement, this is not the case in the adverse domination context because no third parties are involved, and there is no concern with third party reliance on the acts of the principal's agent. Indeed, courts applying adverse domination under these agency principals have recognized that negligence is sufficient to invoke the discovery rule. See, e.g., Resolution Trust Corp. v. Smith, 872 F. Supp. 805, 813 (D. Or. 1995) (citing the Restatement and holding that " $[\mathrm{t}] \mathrm{he}$ knowledge of the defendants cannot as a matter of law be imputed to [the bank] for the purposes of claims against them for negligence, breach of fiduciary duty, and breach of contract"); Resolution Trust Corp. v. Scaletty, No. 72,230, 1995 WL 111986, at *8 (Kan. Mar. 17, 1995) (holding that the adverse domination doctrine applies to negligence claims); Clark v. Milam, 452 S.E.2d 714, 719 (W. Va. 1994) (same).

${ }^{199}$ See Resolution Trust Corp. v. Farmer, 865 F. Supp. 1143, 1158 (E.D. Pa. 1994) ("II]f the facts persuade a jury that the statute of limitations should be tolled with respect to the Inside Director Defendants, then it should be tolled as to the Attorney Defendants as well."); Clark v. Milam, 452 S.E.2d 714, 716, 719 (W. Va. 1994) (applying adverse domination to lawyers and accountants); see also Hanna, supra note 61 , at 653 (" $\mathrm{A}$ majority of the cases ... . have accepted that attorneys can exercise domination of an institution ...." ). 
of the plaintiff. ${ }^{200}$ Thus, as long as the cause of action is inherently unknowable, the corporation should be allowed to invoke the doctrine against third parties it would have sued but for the dominating board. There is no reason to refuse to apply the doctrine to third-party defendants against whom the corporation had a cause of action while it was "incapacitated" by lack of knowledge. ${ }^{201}$

Of course, it is important that the underlying causes of action are related to the adverse actions that are alleged against the dominating directors. ${ }^{202}$ A typical situation is where the corporation has a cause of action against the lawyers and accountants who were involved with the breach of duty by the culpable directors. If claims against such third parties arise out of the same cause of action as that against the culpable directors, there is no reason not to apply the doctrine of adverse domination against those third parties. ${ }^{203}$

Despite the strong argument in favor of applying the doctrine to third parties, many courts still refuse to do so. This refusal is usually grounded in a fear that applying the doctrine to third parties would expand liability too much. ${ }^{204}$ As with the culpability requirement, however, the problem lies with the discovery rule as a whole and not with the adverse domination doctrine alone.

${ }^{200}$ See supra notes 44-52 and accompanying text (discussing the discovery rule).

${ }^{201}$ See Farmer, 865 F. Supp. at 1158 (applying the discovery rule to nondirector defendants); Resolution Trust Corp. v. Gardner, 798 F. Supp. 790, 795 (D.D.C. 1992) (same); Clark, 452 S.E.2d at 716, 719 (same); cf. Mosesian v. Peat, Marwick, Mitchell \& Co., 727 F.2d 873, 879 (9th Cir.) (discussing the possibility of tolling due to domination against an outside accountant, but finding insufficient evidence to do so), cert. denied, 469 U.S. 932 (1984).

${ }^{202}$ See Gardner, 798 F. Supp. at 795 (stating that the rationale behind the rule is that the insiders are afraid of revealing their own wrongdoing); Clark, 452 S.E.2d at 718-19 (stating that the causes of action must be related to the domination of the company).

${ }^{203}$ See Farmer, 865 F. Supp. at 1158 (applying the discovery rule against outside parties without regard to their status as negligent or nonnegligent, even though the court had earlier required that the inside parties' conduct rise to a culpability level greater than negligence).

${ }^{204}$ See, e.g., Federal Deposit Ins. Corp. v. Shrader \& York, 991 F.2d 216, 227 (5th Cir. 1993) (stating that the "narrow doctrine" of adverse domination should not be applied to nonofficers and nondirectors), cert. denied, 114 S.Ct. 2704 (1994). 


\section{Burden of Proof}

The final boundary of the adverse domination doctrine concerns which party should bear the burden of proving that the board was macro-dominated. Courts have not been consistent in deciding this issue. ${ }^{205}$ This section will argue that, under a discovery rule analysis, the plaintiff should bear the burden of proof.

Discovery rule cases generally hold that once the defendant has proven that the claim is otherwise barred, the plaintiff bears the burden of proving that the statute should be tolled. ${ }^{206}$ Of the cases addressing the adverse domination doctrine, both Farmer and Clark have adopted this approach. ${ }^{207}$

Contrary to discovery rule principles, the Hecht court believed that the burden should be on the defendant because she has better access to relevant information. The Hecht court stated that putting "this burden upon the defendants who control the corporation's information shifts the balance more fairly between the defendants and the corporation." 208 Although the court is correct in its assertion that the information is difficult to discover because it is largely in the control of the defendants, it does not follow that this situation is so unfair as to negate the normal operation of the discovery rule. ${ }^{209}$ Director misconduct is no more difficult to discover than a sponge in the body of a patient or an attorney's

${ }^{205}$ See supra part II.B.4.

${ }^{206}$ See Shrader, 991 F.2d at 220 ("In Texas, the party seeking to benefit from the discovery rule "bear[s] the burden of proving and securing favorable findings thereon." (alteration in original) (quoting Woods v. William M. Mercer, Inc., 769 S.W.2d 515, 518 (Tex. 1988))); Balsavage v. Ryder Truck Rental, Inc. 712 F. Supp. 461,470 (D.N.J. 1989) (placing the burden of proof on the plaintiff to "establish[] a favorable date of discovery"); Gunsalus v. Celotex Corp., 674 F. Supp. 1149, 1155 (E.D. Pa. 1987) (stating that "the burden of proof is on plaintiff to show that the discovery rule applies ${ }^{n}$ ); Owens v. Lac D'Amiante Du Quebec, Ltee., 656 F. Supp. 981, 982 (E.D. Pa.) ("Although defendants bear the burden of proof on the statute of limitations defense . . plaintiffs bear the burden of proving that the discovery rule should apply."), affd, 833 F.2d 306 (3d Cir. 1987); Doe v. Cherwitz, 518 N.W.2d 362, 364 (Iowa 1994) (stating that the plaintiff bears burden of proving when "the alleged victim discovered the injury or, in the exercise of reasonable care, should have discovered it" for statute of limitation purposes); Palenkas v. Beaumont Hosp., 443 N.W.2d 354, 364 (Mich. 1994) (holding that "it is consistent both for the defendant to have the initial burden of production on its affirmative defense and for the plaintiff to have the ultimate burden of convincing the jury that his claim is timely").

${ }^{207}$ See Farmer, 865 F. Supp. at 1158; Clark v. Milam, 452 S.E.2d 714, 720 (W. Va. 1994).

${ }^{208}$ Hecht v. Resolution Trust Corp., 635 A.2d 394, 408 (Md. 1994).

${ }^{209}$ The Hecht court noted the problems associated with a derivative suit. See id. at 407-08. This, however, only explains why the discovery rule should apply. 
malpractice. In each of these situations, the defendant has better access to the relevant information, yet the courts still place the burden of proof on the plaintiff. Indeed, Judge Bell dissented in Hecht on this very issue, arguing that the plaintiff should bear this burden. ${ }^{210}$

\section{TOWARD REPOSE}

This Comment has proposed the proper boundaries of the adverse domination doctrine under a discovery rule analysis. The doctrine should only apply when the plaintiff can show that the board was macro-dominated. Macro-domination in the adverse domination context requires that all directors be culpable except those who are uninformed or unknowledgeable. Furthermore, the doctrine should be invoked for purely negligent acts of directors $^{211}$ and against third parties whose negligent actions are directly related to such actions of the directors. The burden of proof should be placed on the plaintiff. This is a correct formulation of the adverse domination doctrine based on the theory and principles of the discovery rule; however, the question remains whether this is an acceptable doctrine. To understand the potentially harsh consequences of such a doctrine consider the following example:

John and Sally open a closely held banking corporation, Best Bank, Inc., in 1950. Together they own two-thirds of the shares of the corporation; the other third is held by their cousin, Tim. John and Sally are the only directors of the corporation. Tim is not involved in the day-to-day operations of Best Bank and is a silent minority shareholder-he simply lent his money to John and Sally hoping for a large return.

In 1951, while still new at the business, John and Sally make a large loan upon the advice of their accounting firm, Cash \& Spend. Unfortunately for John and Sally, they did not investigate the loan as thoroughly as they should have. In 1955 the debtor defaults, and the company loses a significant amount of money. John and Sally continue to run the corporation successfully for the

${ }^{210}$ Judge Bell took issue with the authority used to support the majority's position that defendants bear the burden on statute of limitations issues. He believed that, generally, it is the plaintiff who bears the burden of showing that the statute of limitations is tolled. See id. at 410-11 (Bell, J., dissenting).

${ }^{211}$ Directors, except in certain limited situations, must be grossly negligent to be liable to the corporation. See supra note 88 and accompanying text (discussing the business judgment rule). 
next thirty years. In 1990 they retire and sell their interest to Tim, who takes over the company and becomes the sole director of the company. In 1991 Tim discovers the bad loan made in 1951 and initiates a suit against John, Sally, and Cash \& Spend on behalf of the company. Tim and Best Bank attempt to invoke the adverse domination doctrine.

Tim and Best Bank have an excellent opportunity to prevent the accrual of the cause of action for forty years. John and Sally completely dominated the board of directors for the entire forty years, so it was impossible for the corporation to learn of the adverse actions of the directors. ${ }^{212}$ The directors and the accounting firm were probably negligent in their failure to carefully investigate the claim. ${ }^{213}$ Therefore, the parties are sufficiently culpable to allow tolling under the adverse domination doctrine as analyzed in connection with the discovery rule. ${ }^{214}$ Finally, Cash \& Spend would also be subject to tolling because it is liable on a cause of action arising out of the same cause of action for which the dominating directors would be liable. ${ }^{215}$

If this result seems extreme, it should. Tolling the statute of limitations against directors and accountants for negligent acts that happened a half century ago seems outrageous. It is not surprising that courts have balked at creating an interpretation of adverse domination that could lead to such a result. But the problem here is of the judges' own making. The judiciary is largely responsible for the expansive use of the discovery rule. ${ }^{216}$ It is interesting that judges hesitate to expand the discovery rule in the corporate

${ }^{212}$ See supra part IV.A (discussing levels of domination and the inability of the corporation to discover adverse actions).

${ }^{213}$ Directors have an obligation to fully investigate their business decisions. See, e.g., Smith v. Van Gorkom, 488 A.2d 858, 872 (Del. 1985) ("The determination of whether a business judgment is an informed one turns on whether the directors have informed themselves 'prior to making a business decision, of all material information reasonably available to them." (quoting Aronson v. Lewis, 473 A.2d 805, 812 (Del. 1984))). Officers and directors of financial institutions are held to an even higher standard. See 1 KNEPPER \& BAILEY, supra note 90, § 11-1, at 399 ("The tendency has been to hold directors of depository institutions to a more stringent liability standard than directors of business corporations ....").

${ }^{214}$ See supra part IV.B (discussing negligence as a sufficient level of culpability for corporate directors).

${ }^{215}$ See supra part IV.C (discussing the applicability of the adverse domination doctrine to third parties).

${ }^{216}$ See Heriot, supra note 12, at 954 (noting that American courts have "engraft[ed] everexpanding discovery rules into statutes of limitation"); Developments, supra note 11, at 1200 (noting that courts have altered the limitations period through liberal interpretation of the word "accrue"). 
context but not in the area of other torts, such as malpractice and products liability. The same example cited above could easily apply to a medical malpractice case. What if a sponge left in a patient did not cause harm until forty years after it was left there?

It seems that the important underlying policy of the statute of limitations, repose, ${ }^{217}$ has been abandoned completely by the courts' creation of far-reaching discovery rules. ${ }^{218}$ Allowing a fortyyear-old claim to proceed would seem to undermine completely what the Supreme Court found to be the important purpose of statutes of limitations: "to promote justice by preventing surprises through the revival of claims that have been allowed to slumber until evidence has been lost, memories have faded, and witnesses have disappeared." 219

\section{A. Problems with the Death of Repose $e^{220}$}

One of the most important virtues of repose is that it allows people to better estimate their potential liability and, therefore, plan for the future. ${ }^{221}$ A rational director will choose whether to serve on a board based on a consideration of the benefits she expects to draw from the position balanced against the costs and potential risks she associates with the job. ${ }^{222}$ Directors expect that they may be subject to liability, and they therefore purchase insurance to cover this risk. ${ }^{223}$ Under a liability scheme with an expansive

${ }^{217}$ See supra notes 21-22 and accompanying text (discussing the proposition that repose to defendants is the primary underlying purpose of statutes of limitations).

${ }^{218}$ See Heriot, supra note 12, at 961 ("[C]ourts have adopted discovery rules that make it extremely difficult for defendants ever to feel secure.").

${ }^{219}$ Order of R.R. Telegraphers v. Railway Express Agency, Inc., 321 U.S. 342, 348 49 (1944).

${ }^{220}$ The problems related to balancing the repose to be given to a corporate officer against the right of a plaintiff to recover for wrongful conduct extend well beyond the scope of this Comment. Instead, this section of the Comment simply illustrates that adverse domination is another weight on the scales that tilts the balance away from repose. A primary purpose of this section is to further academic, legislative, and judicial debate on the balance to be struck between repose and the plaintiff's right to recovery in corporate domination cases.

${ }^{221}$ See RICHARD A. POSNER, ECONOMIC ANALYSIS OF LAW $\$ 21.15$, at 587 (4th ed. 1992) (noting that one purpose of statutes of limitations is "to enable people to plan their activities with greater certainty"); Leslie, supra note 11, at 1590 ("In this way, preventing unfair surprise accommodates business planning and protects the reasonable expectations of potential defendants."); $c f$. Josephine $\mathrm{H}$. Hicks, Note, The Constitutionality of Statutes of Repose: Federalism Reigns, 38 VAND. L. REV. 627, 632-33 (1985) (discussing how repose leads to more certainty in insurance rates).

${ }^{222}$ See generally POSNER, supra note $221, \$ \S 1.1-.3$ (discussing the economic values and costs associated with various choices of action).

${ }^{223}$ See 2 KNEPPER \& BAILEY, supra note 90, §23-1, at 335-37 (discussing the 
discovery rule, however, a director's term of potential liability becomes less certain. The potential variability in repose for defendants will increase risk and therefore make insurance premiums more expensive. ${ }^{224}$ In addition, other recent developments in director liability have already made it more difficult for directors to obtain insurance, ${ }^{225}$ and the potential increase in the time period in which these directors may be subject to liability may make insurance even more difficult to obtain. All of these factors will tend to discourage qualified people from serving on boards of directors. The law must grant some measure of repose after a reasonable period of time if it wants to encourage capable people to serve on boards of directors.

Another important problem with the judicial expansion of discovery rules has been pointed out in a discussion by Professor Gail Heriot. ${ }^{226}$ Legislatures create statutes of limitations for a purpose-namely, for granting repose to defendants and increasing judicial efficiency by preventing stale claims. ${ }^{227}$ The function of courts is to interpret legislation, not to rewrite it. ${ }^{228}$ Statutes of

importance of director and officer liability insurance); Richard A. Myers, Jr., Where Have All the Directors Gone: Corporate Director and Officer Liability and Coping with the Insurance Crisis, 36 CLEV. ST. L. REv. 575, 576 (1988) ("Traditional protection . . . in past years has been director and officer liability insurance.").

${ }^{224}$ See Scott, supra note 48, at 332 ("The effects of the new rule will include increased litigation, undetermined exposure to liability, and probable increased insurance costs."); Hicks, supra note 221, at 632-33 ("Theoretically, by cutting off a defendant's liability after a given number of years, statutes of repose lead to more certain liability and thus provide greater actuarial precision in setting insurance rates.").

${ }^{225}$ Much of this difficulty is related to the Delaware Supreme Court's decision in Smith v. Van Gorkom, 488 A.2d 858 (Del. 1985), which applied a standard of "gross negligence" to directors' decisions that many commentators thought was closer to simple negligence than gross negligence. See Larry D. Soderquist, The Proper Standard for Director's Negligence Liability, 66 NOTRE DAME L. REv. 37, 37 (1990) (discussing the impact of Van Gorkom on director insurance); see also Myers, supra note 223, at 576 (" $[I]$ nsurers have been prompted to either cease writing director and officer coverage or to provide such coverage at greatly inflated premiums with an increased number of exclusions.").

${ }^{226}$ See generally Heriot, supra note 12 (arguing for legislative preference of a rulelike statute of limitations).

${ }^{227}$ See supra notes $20-25$ and accompanying text.

${ }^{228}$ See Efrat M. Cogan, Note, Executive Nonacquiescense: Problems of Statutory Interpretation and Separation of Powers, 60 S. CAL. L. REv. 1143, 1153 (1987) (noting that "when the judiciary interprets statutory law, it does so with the knowledge that the legislature can alter such an interpretation so that it conforms to majoritarian desires"); Craig W. Dallon, Note, Interpreting Statutes Faithfully-Not Dynamically, 1991 B.Y.U. L. REv. 1353, 1354 (noting that "dynamic statutory interpretation is not desirable ${ }^{n}$ ). See generally Antonin Scalia, The Rule of Law as a Law of Rules, 56 U. CHI. 
limitations were created as legal rules setting forth a specific period after which a claim could not be brought. ${ }^{229}$ By incorporating expansive discovery rules into statutes of limitations, the result is a rule of law that is "stripped of much of its rulelike character. ${ }^{\text {230 }}$

One could argue that by using the word "accrue," legislatures impliedly grant discretion to courts to determine the period of time in which an action can be brought. ${ }^{231}$ Indeed, some legislatures have even created specific discovery rules by statute. ${ }^{232}$ It does not seem reasonable, however, that a legislature would have intended to allow a court to postpone accrual on a cause of action for forty years. ${ }^{233}$ Such a scenario undermines the legislative policies that were the basis of statutes of limitations. ${ }^{234}$ Why would a legislature create a two-year limitation for tort actions if it were possible to sue forty years after the tort occurred?

\section{B. A Legislative Solution}

It seems reasonable to assume that courts have incorporated discovery rules into statutes of limitations because they believe that in many cases the limitations provided by the legislature are too short. Legislatures have often done little to respond to the increasingly loose standards applied by the courts; and, to some degree, the courts may be justified in the theory that the legislature has deferred to them. ${ }^{235}$ The legislature, however, must not shirk

L. REv. 1175 (1989) (exploring the dichotomy between general rules and personal discretion in the context of law made by the courts).

${ }^{229}$ See Heriot, supra note 12, at 923-27 (noting that while there has long been "a desire to keep stale cases out of the courts, in practice this policy has been applied in an uneven and erratic manner").

${ }^{230} \mathrm{Id}$. at 960.

${ }^{231}$ See id. at 960-61 (noting the argument that "[c]ourts that have adopted expansive discovery rules have done so with the implicit consent of legislatures"); Developments, supra note 11, at 1200 (noting that courts use the word "accrue" as the springboard for their intervention).

${ }^{232}$ See, e.g., ALA. CODE $\$ 7-2-725$ (1993) (discovery rule for the sale of goods); ALASKA STAT. $\$ 45.02 .725$ (1962) (same); CAL. CIV. PROC. CODE $\$ 340.1$ (West 1995) (discovery rule for childhood sexual abuse cases).

${ }^{233} C f$. Heriot, supra note 12 , at 962 ("When an expansive discovery rule was added ... the balance struck by the legislature between the plaintiff-focused principle and the defendant-focused principle was jarred massively out of kilter. It hardly seems likely that this would appeal to legislatures." ).

${ }^{234}$ See id.; see also supra notes 21-22 and accompanying text (discussing the repose purpose of statutes of limitations).

${ }_{235}$ See Heriot, supra note 12, at 963-67 (discussing the problems faced by legislatures in trying to control the courts' use of discovery rules). 


\section{its responsibility.}

A reasonable response to the problem would be to combine the shorter limitations period with a longer statute of repose. Statutes of limitations and statutes of repose are often confused but are, in fact, two distinct types of statutes. ${ }^{236}$ Statutes of limitations are the statutes that have been discussed thus far in this Comment. Statutes of repose, on the other hand, grant an absolute period within which a suit must be brought. ${ }^{237}$ Statutes of repose are not subject to tolling. ${ }^{238}$

Some states have already combined statutes of limitations with longer statutes of repose in response to the expansive use of the discovery rule in medical malpractice cases. ${ }^{239}$ Given the potentially broad sweep of the adverse domination doctrine, a similar solution seems appropriate in the context of director liability. Legislatures could enact statutes that read as follows:

A suit arising out of a claim for breach of duty against an officer or director may be brought within two years after the cause of action accrues, but in no event later than ten years from the date of the alleged tortious conduct. ${ }^{240}$

${ }^{236}$ See Hicks, supra note 221, at 628-29 ("Although both prescribe the time period within which plaintiffs must bring suit, important differences exist between statutes of limitations and statutes of repose."); Leslie, supra note 11, at 1591 ("Statutes of limitation are sometimes called statutes of repose. However, there is a distinction." (footnote omitted)).

${ }_{237}$ See, e.g., FLA. STAT. ANN. \$ 95.11(4)(b) (West 1982) (providing that medical malpractice action accrues at time of discovery, but "in no event shall the action be commenced later than 4 years from the date of the incident or occurrence out of which the cause of action accrued ${ }^{n}$ ); Lampf, Pleva, Lipkind, Prupis \& Petigrow v. Gilbertson, 111 S. Ct. 2773, 2782 (1991) (establishing a three-year statute of repose for 10b-5 actions); Hicks, supra note 221, at 629 (noting that statutes of repose place an absolute restriction on the time period in which a plaintiff may bring suit).

${ }^{238}$ See AdOLPH J. LEVY, SOlving Statute OF LIMITATIONS PROBLEMS \$ 3.01 (1987) ("[A] statute of repose may commence and may run before the cause of action accrues-even before the plaintiff was injured."); Leslie, supra note 11, at 1591 ("W] $[W e n$ applying statutes of repose, judges can not employ their equitable powers in tailoring the law to the specific circumstances.").

${ }^{239}$ See, e.g., FLA. STAT. ANN. \$ 95.11(4)(b) (setting forth a two-year statute of limitations and a four-year statute of repose for medical malpractice actions); $G A$. CODE ANN. \$ 9-3-71(c) (Supp. 1994) ("Subsection (a) of this Code section is intended to create a two-year statute of limitations. Subsection (b) of this Code section is intended to create a five-year statute of ultimate repose and abrogation."); $f f$. IND. CODE ANN. § 27-12-7-1 (West Supp. 1994) (creating a statute of repose for medical malpractice cases).

${ }_{240} C$ f. FLA. STAT. ANN. $\$ 95.11(4)(b)$ (providing a similarly worded statute for medical malpractice claims); GA. CODE ANN. \$ 9-3-71(a), (b) (Supp. 1994) (same); Hicks, supra note 221, at 629 (" $[\mathrm{A}]$ products liability statute may provide that an action must be brought within six years of injury but in no event may a plaintiff 
This type of statute would allow a court to toll the statute of limitations based on adverse domination for up to ten years after the allegedly tortious conduct, but thereafter, the claim would be absolutely barred. In essence, the legislature would be giving the courts leeway to toll the statute of limitations when it would be just to do so. The legislature, however, would also be insuring some measure of repose by setting an outer limit beyond which suit could not be brought. ${ }^{241}$ Thus, a fair balance would be struck between repose for defendants and fairness to plaintiffs.

Indeed, application of the adverse domination doctrine under a combination statute of repose/statute of limitations seems to have been accepted by at least one court. ${ }^{242}$ The Kansas statute of limitations for torts provides that a cause of action will accrue when discovered but that "in no event shall an action be commenced more than 10 years beyond the time of the act giving rise to the cause of action. ${ }^{243}$ In Resolution Trust Corp. v. Scaletty, ${ }^{244}$ the Kansas Supreme Court adopted adverse domination as a variation of the discovery rule under the discovery rule portion of the Kansas limitation statute. ${ }^{245}$ Thus, it is clear that the proposal advocated in this Comment could indeed work in practice.

\section{CONCLUSION}

This Comment has attempted to clear up some of the confusion pervading application of the adverse domination doctrine to suits brought by the RTC and the FDIC. By determining that the nature of the adverse domination doctrine is most closely related to the discovery rule, a uniform rule has been discerned for courts to apply. Given that state law governs the tolling of statutes of limitations under FIRREA, ${ }^{246}$ it is especially important that federal courts understand the origins of the doctrine. Knowing that adverse domination is essentially a variant of the discovery rule, a

commence an action more than ten years after the date on which the product was first purchased.").

${ }^{241}$ See Heriot, supra note 12, at 962 (noting that this solution "is a particularly interesting one in that it accommodates to some extent the changing times argument without wholly sacrificing protection for the potential defendant").

${ }^{242}$ See Resolution Trust Corp, v. Scaletty, No. 72,230, 1995 WL 111986, at *6 (Kan. Mar. 17, 1995).

${ }^{243}$ KAN. STAT. ANN. \$ 60-513(b) (1994).

${ }^{244}$ No. 72,230, 1995 WL 111986 (Kan. Mar. 17, 1995).

${ }^{245}$ See id. at $* 6$.

${ }^{246}$ See supra notes 65-67 and accompanying text. 
federal court should consult state law surrounding the discovery rule. Not only will this lead to a more uniform version of adverse domination being applied in federal courts, it will also ease the difficult position of a federal court asked to apply a doctrine not yet adopted in the state in which it sits. The body of law on the discovery rule is extensive in most states, and a federal judge who understands that adverse domination is simply a variant of the discovery rule will find her task much easier if she knows to consult this body of law instead of attempting to mold state law in federal court.

As the number of cases involving adverse domination grows, this Comment should serve as a useful reference for understanding the theoretical basis for and application of the doctrine. This Comment should also further discussion and debate about the appropriate balance between the plaintiff's right to recover for legitimate injuries and the need for defendants, at some point, to feel secure in their affairs. Adverse domination seems to be the most expansive use of the discovery rule to date. As the balance tips increasingly in favor of plaintiffs, it is time that courts, legislatures, and academics reconsider the purposes, policies, and applications of statutes of limitations. The literature on statutes of limitations is disappointingly sparse. Ideally, this Comment will serve to revitalize discussion of the important issues surrounding limitations on causes of action. 
